\title{
ZnO nanoparticles (ZnO-NPs) and their antifungal activity against coffee fungus Erythricium salmonicolor
}

\author{
P. A. Arciniegas-Grijalba ${ }^{1}$ - M. C. Patiño-Portela ${ }^{1}$ L. P. Mosquera-Sánchez ${ }^{1}$ \\ J. A. Guerrero-Vargas ${ }^{2}$ J. E. Rodríguez-Páez ${ }^{3}$
}

Received: 3 March 2017 / Accepted: 2 April 2017/Published online: 9 April 2017

(c) The Author(s) 2017. This article is an open access publication

\begin{abstract}
In this work, a methodology of synthesis was designed to obtain $\mathrm{ZnO}$ nanoparticles ( $\mathrm{ZnO} \mathrm{NPs}$ ) in a controlled and reproducible manner. The nanoparticles obtained were characterized using infrared spectroscopy, $\mathrm{X}$-ray diffraction, and transmission electron microscopy (TEM). Also, we determined the antifungal capacity in vitro of zinc oxide nanoparticles synthesized, examining their action on Erythricium salmonicolor fungy causal of pink disease. To determine the effect of the quantity of zinc precursor used during $\mathrm{ZnO}$ NPs synthesis on the antifungal capacity, 0.1 and $0.15 \mathrm{M}$ concentrations of zinc acetate were examined. To study the inactivation of the mycelial growth of the fungus, different concentrations of $\mathrm{ZnO}$ NPs of the two types of synthesized samples were used. The inhibitory effect on the growth of the fungus was determined by measuring the growth area as a function of time. The morphological change was observed with high-resolution optical microscopy (HROM), while TEM was used to observe changes in its ultrastructure. The results showed that a concentration of $9 \mathrm{mmol} \mathrm{L}^{-1}$ for the sample obtained from the $0.15 \mathrm{M}$ and at $12 \mathrm{mmol} \mathrm{L}^{-1}$ for the $0.1 \mathrm{M}$ system significantly inhibited growth of $E$. salmonicolor. In the HROM images a deformation was
\end{abstract}

J. E. Rodríguez-Páez

jnpaez@unicauca.edu.co

1 Grupo de Investigación en Microscopia y Análisis de Imágenes (GIMAI), Universidad del Cauca-Popayán, Popayán, Colombia

2 Grupo de Investigaciones Herpetológicas y Toxinológicas (GIHT), Departamento de Biología, Universidad del CaucaPopayán, Popayán, Colombia

3 Grupo CYTEMAC, Departamento de Física, Universidad del Cauca-Popayán, Popayán, Colombia observed in the growth pattern: notable thinning of the fibers of the hyphae and a clumping tendency. The TEM images showed a liquefaction of the cytoplasmic content, making it less electron-dense, with the presence of a number of vacuoles and significant detachment of the cell wall.

Keywords Nanoparticles $\cdot \mathrm{ZnO} \cdot$ Synthesis $\cdot$ Antifungal, E. salmonicolor

\section{Introduction}

Zinc oxide $(\mathrm{ZnO})$ is one of the inorganic compounds with the greatest scientific and technological importance (Klingshirn 2007a, b; Özgür et al. 2005; Pearton et al. 2005), a condition continuously reinforced by the opening up of new technologies, where the functionality of $\mathrm{ZnO}$ can take on ever more exciting roles (Moezzi et al. 2012) given its optical properties (Djurišić and Leung 2006; Jagadish and Pearton 2011; Klingshirn et al. 2010; Morkoç and Özgür 2008), its semiconductor nature (Janotti and Van de Walle 2009; Klingshirn et al. 2010; Morkoç and Özgür 2008), and the physicochemical surface properties (Wöll 2007). $\mathrm{ZnO}$ is a direct band gap semiconductor (Vogel et al. 1995) with an experimental energy value of $3.37 \mathrm{eV}$. Due to its wide band gap and large exciton binding energy of $60 \mathrm{meV}$ at room temperature, this oxide is very attractive for applications such as optoelectronic devices and for use as photodegradation material. Based on the characteristics mentioned and on other properties indicated and adequately described in the literature (Jagadish and Pearton 2011; Klingshirn et al. 2010; Moezzi et al. 2012; Morkoç and Özgür 2008), the technological uses of $\mathrm{ZnO}$ are extremely broad and diverse, standing out for its volume of 
use as a photoconductive ingredient (Blakeslee et al. 1962), as an activator in the industrial vulcanization of rubber (Nieuwenhuizen 2001), and in pigments and coatings (Auer et al. 1998), among others. Since $\mathrm{ZnO}$ is normally catalogued as a non-toxic material (Patnaik 2003), it is used in a wide range of cosmetic products, including moisturizers, lip products, mineral make-up bases, face powders, ointments, lotions, and hand creams (Nohynek et al. 2007). The production of nanoparticles, and nanostructures in general, has led to an increased interest in $\mathrm{ZnO}$, taking into account the potential use in fields such as environmental remediation (Kisch 2015; Lead and Smith 2009; Lu and Pichat 2013).

Regarding the production of $\mathrm{ZnO}$, the oxide has been synthesized by a range of methods (Kołodziejczak-Radzimska and Jesionowski 2014), including the following: precipitation (Rodríguez-Páez et al. 2001); Pechini-polymer complex (Avila et al. 2004), combustion (Guo and Peng 2015), sol-gel (Alwan et al. 2015); hydrothermal (Hardy et al. 2009), mechanochemical (Anand et al. 2014), hydro/solvo-thermal (Yan and Chuan-Shang 2009), and polyol process (Dakhlaoui et al. 2009), among others.

Due to their nanoscale size, the different morphologies they can have, and their high specific surface area, nanoparticles show high chemical reactivity, high surface adsorption capacity, and high surface charge. These are factors that enable them to interact very efficiently with biological systems, causing significant toxicity (Cassaignon and Colbeau 2013; Kahru and Dubourguier 2010; Ray et al. 2009). Although progress has been made in understanding toxicological and environmental effectsboth direct and indirect- that are generated by interaction with nanoparticles, this subject has not been fully explored. General principles require to be drawn from case studies (from relevant, environmental examples) to determine the behavior of nanoparticles as well as their biological effects (Cassaignon and Colbeau 2013; Houdy et al. 2011; Rahman et al. 2013).

There is currently a great scientific and technological interest in nanoparticles and metal oxides, including $\mathrm{ZnO}$ (Bréchignac et al. 2007; Klabunde and Richards 2009). Knowledge about their biological effects has generated a great deal of interest, giving rise to the special name of "nanotoxicology", a term coined in 2005 by Oberdörster et al. (2005). Numerous articles have been published and very comprehensive compilations produced on the subject (Bréchignac et al. 2007; Zucolotto et al. 2013). Considering their toxicity, the potential use of nanoparticles for controlling phytopathogenic fungi has generated great interest (Ram et al. 2011; Zucolotto et al. 2013), motivated by prior studies that show the effective antifungal activity of different nanoparticle materials including silver (Kumar et al. 2008), copper (Cioffi et al. 2005; León et al. 2011), titanium dioxide (Maneerat and Hayata 2006), and zinc oxide (Lipovsky et al. 2011). Specifically, working in aqueous systems or those in which it was possible to dissolve the $\mathrm{ZnO}$ NPs and thus generate $\mathrm{Zn}^{2+}$ in the medium, two effects were considered in analyzing $\mathrm{ZnO}$ toxicity: the first dependent on the particle and the second effect being promoted by the dissolved $\mathrm{Zn}^{2+}$, mechanisms that would have different modes of action, as demonstrated by Poynton et al. (2010) working with D. magna. Other factors that would affect the solubility of $\mathrm{ZnO} N \mathrm{NP}$ and, therefore, the contribution of the $\mathrm{Zn}^{2+}$ ions to oxide toxicity are the presence of certain anions $\mathrm{Cl}^{-}$and $\mathrm{SO}_{4}{ }^{2-}$ for example (Ma et al. 2013), temperature (Reed et al. 2012), the presence of organic material (Miao et al. 2010) — very important for the present work-and the presence of phosphate in the medium, as shown by Mingua et al. (2010) and Reed et al. (2012) in their studies.

Although there is no consensus on the exact mechanism that generates toxicity induced by the $\mathrm{ZnO}$ NPs, the most accepted view is that this type of toxicity is usually mediated by ROS that would be generated on the surface of the particle. These species might occur as a result of the electronic properties of the semiconductor material and/or the capacity of the ZnO NPs to disrupt electron transfer processes in biological systems, which could occur in the mitochondrial inner membrane (Xia et al. 2008), such as the reaction of the surface of the ZnO NPs with water, producing hydroxyl radicals (OH.) (Sapkota et al. 2011) or $\mathrm{H}_{2} \mathrm{O}_{2}$ (Sawai et al. 1998).

Furthermore, different mechanisms ought to be put forward for different fungi, as illustrated in the study of Botrytis cinerea and Penicillium expansum using Raman spectroscopy. In this study (He et al. 2011), researchers showed that in the Raman spectra corresponding to the fungus $B$. cinerea, the intensity of the bands associated with the nucleic acids and carbohydrates increased significantly when treated with $\mathrm{ZnO}$ NPs, while this did not occur with the bands of the proteins and lipids. Sharma et al. (2010) studied the antifungal properties of $\mathrm{ZnO}$ nanoparticles, synthesized with and without the use of surfactants, under different reaction conditions, on strains of Fusarium sp. The antifungal activity of these NPs was compared with the fungus subjected to traditional antifungal treatment using copper sulphate. The results indicated that the antifungal activity of the ZnO NPs depended on the concentration and size of the NP. The latter characteristic was determined by the different reaction conditions used during their synthesis. He et al. (2011) subsequently tested the antifungal effect of $\mathrm{ZnO}$ NPs and their modes of action on two pathogenic postharvest fungi: Botrytis cinerea and Penicillium expansum. The results obtained showed that at concentrations above $3 \mathrm{mmol} \mathrm{L}^{-1}$, the growth of these pathogens was significantly inhibited. 
Moreover, the findings indicated that the antifungal activity of the $\mathrm{ZnO}$ NPs was different for $B$. cinerea and $P$. expansum, since in the first case, growth was inhibited because the nanoparticles directly affected cellular functions, causing deformation in the hyphae of the fungi, while in $P$. expansum there was no development of conidiophores and conidia, which ultimately led to the death of the hyphae.

Based on all that have been outlined above and the antifungal capacity shown by ZnO NPs, this work set out to study the effect of these nanoparticles on a fungus that affects the coffee crop: E. salmonicolor. Coffee, in terms of commercial activity, is a product of great economic importance for Brazil, Vietnam, Colombia, Indonesia, Ethiopia, Peru, India, Honduras, Mexico, and Costa Rica, among others. These countries are the major producers, with an annual global production of about 6.3 million tons per year (Parras et al. 2007). In Colombia, the third largest producer in the world, coffee (Coffea arabica L.) is the second most important resource after oil, with production reaching 10.9 million bags (FNC 2014), making it a vital resource for economic growth and industrial development (Naranjo et al. 2011). Fungi, meanwhile, including $E$. salmonicolor, constitute the main cause of a number of phytopathogenic diseases (Galvis-García 2002) that can take hold in coffee plantations, critically reducing the crop yield and at times managing to destroy entire harvests (Rodríguez 2001). E. salmonicolor is responsible for the disease known as "pink disease" that causes the yellowing and wilting of leaves, stems and fruits, leading to plant death (Galvis-García 2002). To combat the problem, there is a need for research into new antifungal alternatives, for example taking into account the use of nanotechnology, specifically nanoparticles, that enable the physicochemical control of the fungi without altering the eventual harvest.

In this paper, $\mathrm{ZnO}$ nanoparticles were synthesized by a chemical route and displayed certain characteristics defined by synthesis conditions. ZnO NPs were used to carry out a systematic in vitro study, looking at a number of different concentrations to determine the antifungal effect on $E$. salmonicolor. The study also evaluated the effect of varying synthesis parameters, including initial concentration of precursor, on the fungicidal capacity of nanoparticulate $\mathrm{ZnO}$.

\section{Experimental procedure}

\section{Synthesis of ZnO nanoparticles}

To synthesize the $\mathrm{ZnO}$ nanoparticles, the sol-gel method was used. For this, $13.1694 \mathrm{~g}$ of zinc acetate di-hydrate $\left(\left(\mathrm{CH}_{3} \mathrm{COO}\right)_{2} \cdot \mathrm{Zn} \cdot 2 \mathrm{H}_{2} \mathrm{O}\right.$-Merck $)$ was used as a precursor, and $0.07289 \mathrm{~g}$ of surfactant, cetyltrimethyl ammonium bromide $\left(\left(\left(\mathrm{C}_{16} \mathrm{H}_{33}\right) \mathrm{N}(\mathrm{CH} 3)_{3}\right) \mathrm{Br}\right.$-Merck), used to control the growth of the particles. To favor the nucleation process of the solid phase, by means of hydrolysis and condensation reactions, a solution of analytical ethanol $(400 \mathrm{~mL})$ was prepared at a concentration of $[0.15 \mathrm{M}]$ of precursor dispersing the amount of zinc acetate previously indicated, together with the surfactant, and setting the working $\mathrm{pH}$ of the system ( $\mathrm{pH}$ 8.5) by adding, drop by drop, distilled water and ammonium hydroxide $\left(\mathrm{NH}_{4} \mathrm{OH}-\right.$ Baker Analyzed) to the solution. The system was heated to $\sim 70{ }^{\circ} \mathrm{C}$ and maintained under constant stirring for $6 \mathrm{~h}$. The suspension was then allowed to age for 3 days. At the end of this period, the suspension was centrifuged at $5000 \mathrm{rpm}$ for $30 \mathrm{~min}$, and after drying the sample was calcined at $450{ }^{\circ} \mathrm{C}$ in a muffle furnace for $2 \mathrm{~h}$. Figure 1 shows the diagram of synthesis used in this work to obtain ZnO-NPs.

A similar procedure was followed to obtain the $[0.1 \mathrm{M}]$ solution, for which the appropriate amount of zinc precursor was dissolved with the surfactant in $600 \mathrm{~mL}$ of analytical ethanol. In summary, the following were taken as variables of synthesis: the concentration of the precursor and the volume of solvent. This produced two systems referred to as $\mathrm{ZnO} \mathrm{NP}$ 0.15/400 (13.1694 $\mathrm{g}$ of zinc acetate di-hydrate in $400 \mathrm{~mL}$ to give a concentration of [0.15 M]) and $\mathrm{ZnO} \mathrm{NP}$ 0.1/600 (13.1694 g of zinc acetate di-hydrate in $600 \mathrm{~mL}$, giving a concentration of [0.1 M]).

\section{Characterization of the synthesized ZnO NPs}

Once the samples were obtained via the synthesis route described above (Fig. 1), they were characterized using, in the first instance, IR spectroscopy, transmission electron microscopy (TEM), and X-ray diffraction (XRD).

\section{IR spectroscopy}

To determine the different functional groups, the sample to be analyzed was obtained by mixing dry $\mathrm{KBr}$ with the synthesized solid, at a concentration of about $10 \%$. The sweep was carried out between 4000 and $400 \mathrm{~cm}^{-1}$ using the Thermo Nicolet IR 200 spectrophotometer.

\section{Transmission electron microscopy}

To determine the size and morphology of the synthesized $\mathrm{ZnO}$ nanoparticles, these were suspended in $1 \mathrm{~mL}$ of ethanol and placed in an ultrasonic bath for $1 \mathrm{~h}$. Subsequently, with a pasteur pipette, a small amount was taken and deposited on a nickel grid previously coated with a formvar membrane to be observed in the Jeol model JEM 1200 EX transmission electron microscope. 


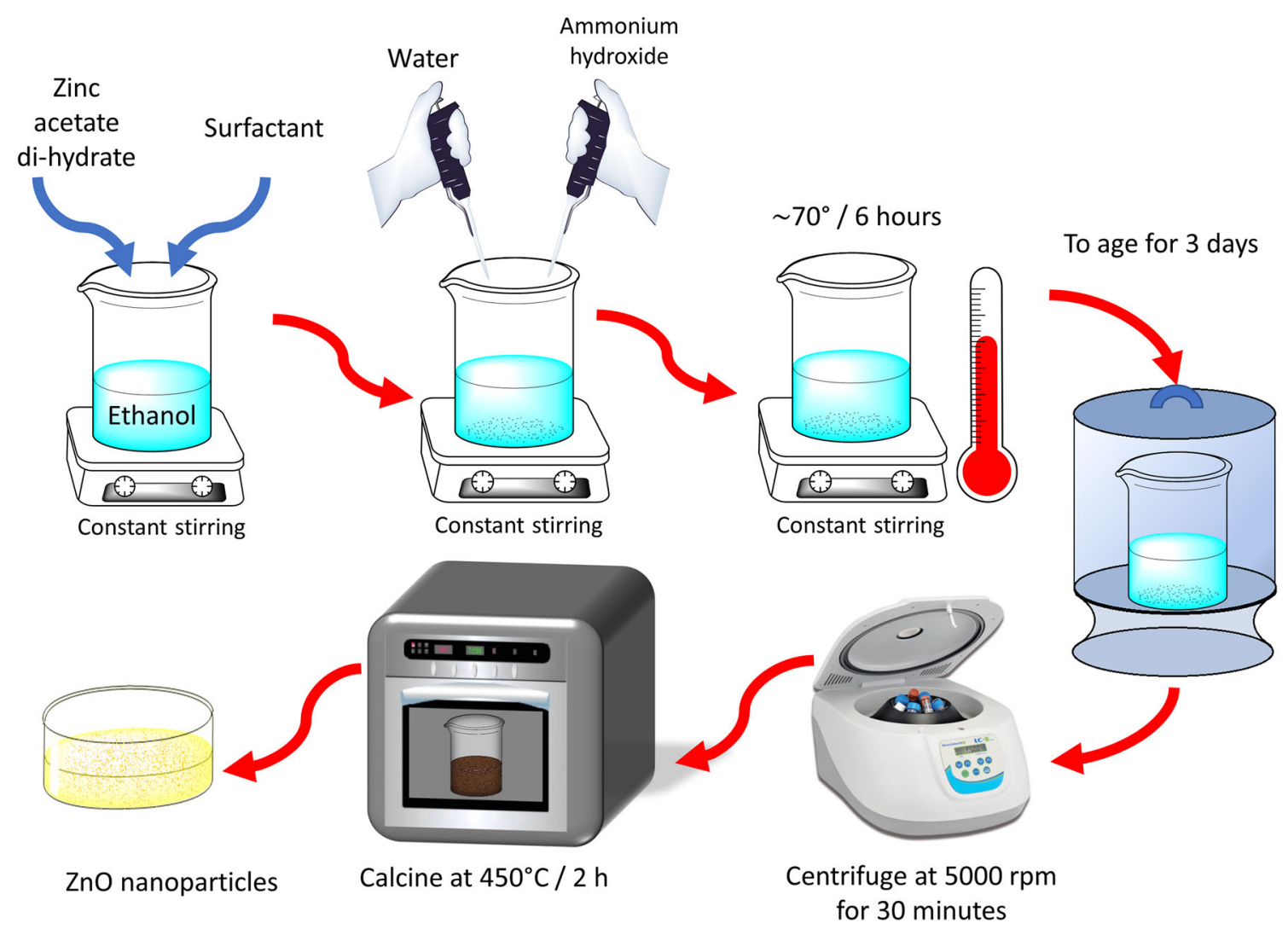

Fig. 1 Synthesis process used to obtain $\mathrm{ZnO}-\mathrm{NPs}$

\section{$X$-ray diffraction}

To determine the crystalline phases present in the solid samples, X-ray diffraction patterns were obtained of the samples of interest in powder form. These were recorded using a Bruker model D8 ADVANCE diffractometer using $\mathrm{K} \alpha$ radiation from the $\mathrm{Cu}(\lambda=1.542 \AA)$ in the range of $10-70$ in $2 \theta$.

\section{Replication of the $\boldsymbol{E}$. salmonicolor fungus strain in the laboratory}

The strains of E. salmonicolor were donated by the National Coffee Research Center (Cenicafe) located in Chinchina, Caldas, Colombia. These strains were replicated and grown in culture media, a potato dextrose agar (PDA) base + oxytetracycline. The media were autoclaved at $121{ }^{\circ} \mathrm{C}$ and then, under a laminar flow hood, they were poured into sterile petri dishes, using $20 \mathrm{~mL}$ in each dish. Finally, they were incubated for 3 days at $25^{\circ} \mathrm{C}$, to ensure sterility, as recommended by the protocol for this type of testing (Lane et al. 2012). At the end of the 3-day incubation, seeding was carried out, inoculating a disc of $1.5 \mathrm{~cm}$ in diameter of mycelium in the center of each petri dish and these strains then incubated to ensure growth (approximately 16 days) under laboratory conditions $\left(25^{\circ} \mathrm{C}\right)$.

The fungi were maintained using the periodic replanting technique that enabled the cultures to survive over short periods of time. This technique is based on transferring the growth from the dry or old medium to a fresh one, providing optimum conditions for fungus growth. In this way, the high risk of contamination and variability of the characteristics of the strains, which represent the main disadvantages, are avoided (Aleman et al. 2005).

\section{Evaluation of antifungal effect of $\mathrm{ZnO}$ NPs on in vitro growth of $E$. salmonicolor}

\section{Preparation of fungal inoculum and bioassays in the culture medium with $\mathrm{ZnO} N \mathrm{NP}$}

To determine the inhibition of mycelial growth of the fungus under study, taking into account the effect of the $\mathrm{ZnO}$ NPs, solid culture media were prepared for the strain using the methodology referred to in "Replication of the $E$. salmonicolor fungus strain in the laboratory". The treatments evaluated were (1) culture medium with no treatment (control); (2) culture medium + copper oxychloride (23.41 mmol L ${ }^{-1}$ ) (fungicide); (3) culture medium $+\mathrm{ZnO}$ 
NP $\left(12 \mathrm{mmol} \mathrm{L}^{-1}\right)$; (4) culture medium $+\mathrm{ZnO} \mathrm{NP}$ $\left(9 \mathrm{mmol} \mathrm{L}{ }^{-1}\right) ; \quad$ (5) culture medium $+\mathrm{ZnO} \quad \mathrm{NP}$ $\left(6 \mathrm{mmol} \mathrm{L}^{-1}\right)$, and (6) culture medium $+\mathrm{ZnO} \mathrm{NP}$ ( $\left.3 \mathrm{mmol} \mathrm{L}^{-1}\right)$. Meanwhile, it is important to clarify that the fungicide, copper oxychloride $\left(\mathrm{Cu}_{2}(\mathrm{OH})_{3} \mathrm{Cl}\right)$, was used as a "benchmark" in the study, as this is commonly employed as a means of preventative control of pink disease (Galvis-García 2002).

The different concentrations of $\mathrm{ZnO}$ NPs were added to the culture medium and subjected to an ultrasonic treatment to ensure their dispersion in the medium; they were then poured into petri dishes, the medium was allowed to solidify, and finally, these systems were incubated for 3 days (see "Results and discussion").

To ensure homogeneity and reproducibility in the seeding process, a fungus of age 16 days was used, from which samples were obtained using a punch of $1.5 \mathrm{~cm}$ diameter, in order to guarantee the existence of growth structures. The mycelia were then inoculated in the center of each petri dish containing the treatment. To obtain reliable results, the experiment was carried out in triplicate.

Seven days were allowed to pass following seeding, in order to ensure an adequate fungal growth and then photographs were taken of the cultures every 3 days. These records were then brought to an image analysis system, "Image Analyzer pro" for measuring the area of growth of the fungus in the Petri dish, continuing until day 25 in total, to observe the action of the treatments over time.

\section{Percent (\%) inhibition}

Inhibition of mycelial growth was determined based on the area of fungal growth, measured in $\mathrm{cm}^{2}$ and expressed in terms of percent inhibition, a parameter calculated using the following formula proposed by Pandey et al. (1982):

$\begin{aligned} \% \text { Inhibition }= & \frac{\text { Growth of control }- \text { Growth of treatment }}{\text { Growth of control }} \\ & \times 100 \quad\end{aligned}$

Identification of morphological and ultrastructural damage to the fungus using high-resolution optical microscopy (HROM) and electron microscopy (TEM)

Processing and preparation of the samples The samples of E. salmonicolor, used for the ultrastructural analysis of the mycelium, were processed according to the standard techniques for TEM protocol (Bozzola and Russell 1999). Small samples of the fungus were placed in vials of $1 \mathrm{~mL}$, fixed overnight in a $2.5 \%$ glutaraldehyde mixture at $4{ }^{\circ} \mathrm{C}$. The following day, the fixer was removed and the samples washed three times with phosphate buffer (PBS) for 5 min each time. They were then postfixed with $1 \%$ osmium tetroxide $\left(\mathrm{OsO}_{4}\right)$ for $1 \mathrm{~h}$ at room temperature and washed again with the buffer, three times for the same 5 min each time.

The postfixed samples were dehydrated with ethanol in ascending concentrations of 30,50,70,80, 90, 95, and $100 \%$, being left in each concentration of alcohol for 10 min. Pre-soaking was carried out with an alcohol and LR white resin mixture in ratios $3: 1,1: 1$, and $1: 3$, the first two ratios for $45 \mathrm{~min}$ each, and the last for $1 \mathrm{~h}$.

Finally, the samples were placed in gelatin capsules, labeled, embedded in LR white resin, and polymerized in a UV chamber at room temperature for $48 \mathrm{~h}$. Once the samples were polymerized, the capsules were taken and carved with a knife to remove the excess resin and thus obtain semi-fine sections of 200-300 nm and ultrafine sections of 40-60 nm. The semi-fine and ultrafine sections were obtained using a glass knife with the aid of a Leica ultramicrotome, model Ultracut R.

\section{High-resolution optical microscopy}

\section{- Imprint.}

Using clear tape, samples were taken directly from the culture media, paying attention to all the treatments and their respective controls. The imprint was then placed on a glass slide, together with a drop of Lactophenol blue. They were then observed using HROM (Nikon Microphot). Images of interest were recorded using a Nikon Digital Sight DS-2Mv linked up to the microscope, using the "Nis Elements" program to capture the images.

\section{- Analysis of semi-thin sections.}

The semi-thin sections of 200-300 nm thickness were fixed, using heat, on the slides by staining with toluidine blue, flaming the plate, and washing with distilled water. They were then observed in the Nikon Microphot light microscope using objectives of $40 \times$ and $100 \times$ in order to select the area of interest where the greatest number of hyphal structures were found arranged transversely and longitudinally. This area was marked out and carved anew to obtain the ultrathin sections.

Transmission electron microscopy Ultrastructural analysis and description of the effect of the ZnO NPs on the pathogen E. salmonicolor were carried out by observing the micrographs taken at different magnifications, using the Jeol model JEM 1200 EX transmission electron microscope, operated at $80 \mathrm{kV}$ (Bozzola and Russell 1999).

\section{- Contrast with uranyl acetate-lead citrate.}

The ultrathin sections, $40-60 \mathrm{~nm}$ thick, and gray to silver in color, were placed together on copper grids coated with formvar membranes. They were contrasted with $4 \%$ 
uranyl acetate for $20 \mathrm{~min}$, using the flotation method in a dark and humid chamber. The sections were washed with drops of distilled water and then placed in contact with a drop of lead citrate for $10 \mathrm{~min}$ in a humid chamber containing pellets of sodium hydroxide $(\mathrm{NaOH})$. Finally, the sections were washed with distilled water, dried with filter paper, and placed in the sample holder of the TEM to be observed (Bozzola and Russell 1999).

Statistical analysis A statistical study was carried out on data relating to the area of fungal growth (measured in $\mathrm{cm}^{2}$ ), a parameter that was recorded periodically. To determine whether the differences observed in this parameter were statistically significant, a hypothesis test was conducted using a design of completely random blocks to compare four concentrations of $\mathrm{ZnO}$ NPs, one concentration of copper oxychloride (reference fungicide) and the control, which constituted the treatments considered in the study (6 in total), and for the seven blocks (days) the action of the treatments over time was examined at 7, 10, 13, 16, 19, 22, and 25 days. All data were subjected to an analysis of distribution fitting and homogeneity of variance, and since these two criteria were met, the ANOVA two-way test was used, carried out in the BioEstat 5.3 (Zar 2014) program; the graphics were constructed using the Graph Pad prism 5 program (Lieber et al. 2006).

\section{Results and discussion}

\section{Characterization of the ZnO NPs synthesized}

\section{Transmission electron microscopy}

For the synthesis of $\mathrm{ZnO}$ NPs, the quantity in grams of the zinc precursor $\left(\mathrm{Zn}\left(\mathrm{CH}_{3} \mathrm{COOH}\right)_{2}\right)$ and the volume of the solvent (ethanol) were taken as variables, i.e. the initial concentration of the precursor was considered as a variable. Following the methodology indicated, the nanoparticles shown in Fig. 2a were obtained, using a 0.15-M concentration of precursor in a volume of $400 \mathrm{~mL}$ of ethanol; this ceramic powder was referred to as $\mathrm{ZnO}$ NP $0.15 / 400$.

The images in Fig. 2a1 show that the synthesized nanoparticles had two types of morphology: (a) spherical and (b) acicular, although looking at the latter more closely, in Fig. 2a2, the needles were formed by the ordered aggregation of the $\mathrm{ZnO}$ nanospheres, a growth mechanism referenced and studied, for other systems, by Bogush and Zukoski (1991). The size of these nanoparticles was in the range between 20 and $35 \mathrm{~nm}$.

Meanwhile, in search of a better dispersion of the nanoparticles, the concentration of the precursor was adjusted, to $0.1 \mathrm{M}$, increasing the volume of solvent in the synthesis to $600 \mathrm{~mL}$, and maintaining constant the amount of surfactant used; this sample was referred to as $\mathrm{ZnO}$ NP $0.1 / 600$ and its morphology and particle size are observed in Fig. 2b. Here, the size of the nanoparticles was in the range between 30 and $45 \mathrm{~nm}$.

It should be noted that during observation of the $\mathrm{ZnO}$ NP 0.1/600 powders, using TEM, the electrons in the beam promoted reactions that caused the nanoparticles to group themselves in a particular way, as illustrated in Fig. 2b2, creating "clusters" containing a finite number of nanoparticles.

By changing the conditions of synthesis, the obtained ceramic powders showed a number of marked differences, including in their state of agglomeration, as illustrated in Fig. 2: while the $\mathrm{ZnO}$ NP $0.15 / 400$ sample produced soft agglomerates, hard clusters or agglomerates were seen with the $\mathrm{ZnO}$ NP $0.1 / 600$. Furthermore, the color of the synthesized samples also changed depending on the synthesis conditions (Fig. 3), the $\mathrm{ZnO} \mathrm{NP} 0.15 / 400$ having a white hue with a slightly darker (Fig. 3a), gray color for the 0.1 $\mathrm{ZnO} \mathrm{NP} / 600$ (Fig. 3b), a characteristic that shows that defect structures in the solids were different. Since $\mathrm{ZnO}$ is a non-stoichiometric solid, it can be found in a variety of colors including white, pale green, light yellow, brown, gray, and even pink, depending on the concentration of defects in the solid, a condition defined in large part by the amount of oxygen present in its crystal structure (Greenwood and Earnshaw 1997).

\section{Infrared spectroscopy}

Figure 4 shows the IR spectra obtained for the samples under consideration. In the spectra, the presence of hydroxyl groups in the band at $\sim 3450 \mathrm{~cm}^{-1}$ and of water molecules in the bending band at $\sim 1630 \mathrm{~cm}^{-1}$ is evident, as is the absence of bands that could be associated with the organic phase of the solid, despite having used organic compounds in the synthesis of the $\mathrm{ZnO}$ nanoparticles. This indicates that the heat treatment at $450{ }^{\circ} \mathrm{C}$ was effective in removing the organic phase.

Since the particular interest of this study lies in the presence of the $\mathrm{Zn}-\mathrm{O}$ and $\mathrm{Zn}-\mathrm{OH}$ bonds involving the $\mathrm{Zn}^{2+}$ cation and whose bands are mainly found between 1000 and $400 \mathrm{~cm}^{-1}$, this specific region of the IR spectrum was used to analyze the differences caused by the changes in the parameters of synthesis (Fig. 5).

The spectra between 1200 and $400 \mathrm{~cm}^{-1}$ in Fig. 5, corresponding to the two solids of $\mathrm{ZnO} \mathrm{NP}$ of interest, show obvious differences in the number of bands and their location: while for the $\mathrm{ZnO} \mathrm{NP} 0.15 / 400$ sample there are two bands (Fig. 5a), one at $450 \mathrm{~cm}^{-1}$ and another at $500 \mathrm{~cm}^{-1}$, as well as a shoulder at $560 \mathrm{~cm}^{-1}$, the $\mathrm{ZnO} \mathrm{NP}$ $0.1 / 600$ shows a single band at $450 \mathrm{~cm}^{-1}$ and a shoulder at 
Fig. 2 Micrographs of a $\mathrm{ZnO}$ NP 0.15/400 and b ZnO NP 0.1/ 600 observed with TEM

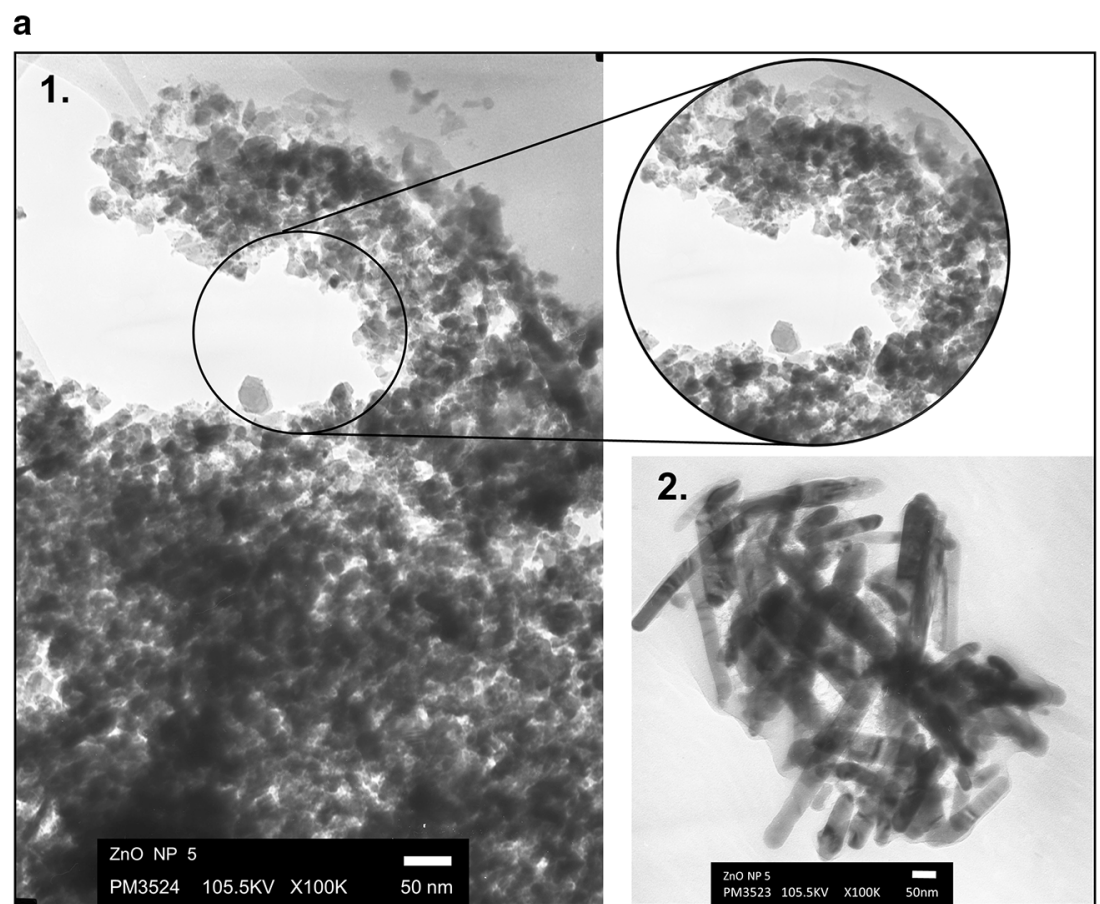

b

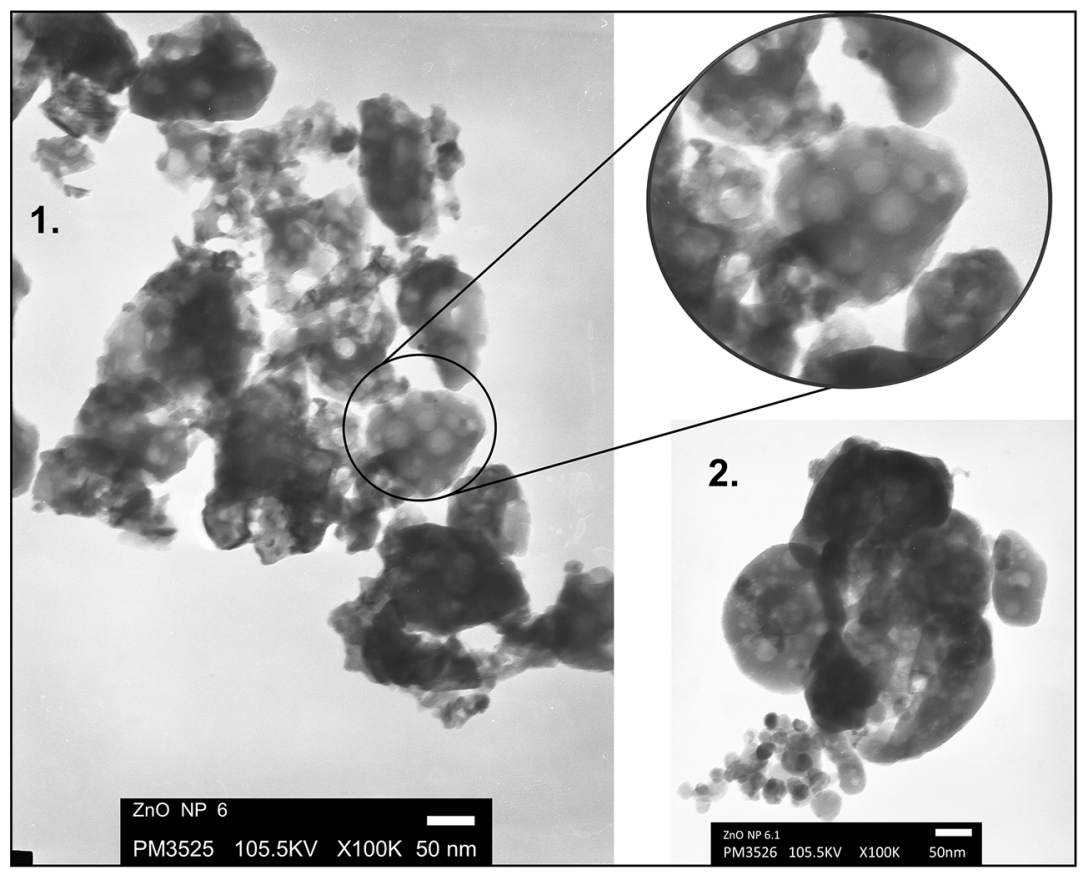

$500 \mathrm{~cm}^{-1}$ (Fig. 5b). This difference in the spectra shows that there have been changes in the environment of the $\mathrm{Zn}-$ $\mathrm{O}$ and $\mathrm{Zn}-\mathrm{OH}$ functional groups, mainly in their quantity and/or arrangement, at the internal and surface level of the solid, changes prompted by the modifications in the parameters of synthesis (Socrates 2004). This seems to indicate, given the structure-properties relationship shown by the materials, that the samples are able to undergo changes in their physical and chemical properties.
$X$-ray diffraction

Figure 6, shows the diffractograms corresponding to the two samples under consideration. The peaks that appear there correspond to the $\mathrm{ZnO}$ (PDF 79-206), as the only crystalline phase present, and the slenderness of the peak indicates good crystallization of the samples. In contrast to the IR spectra in Figs. 4 and 5, in the diffractograms in Fig. 6 there is no obvious difference 

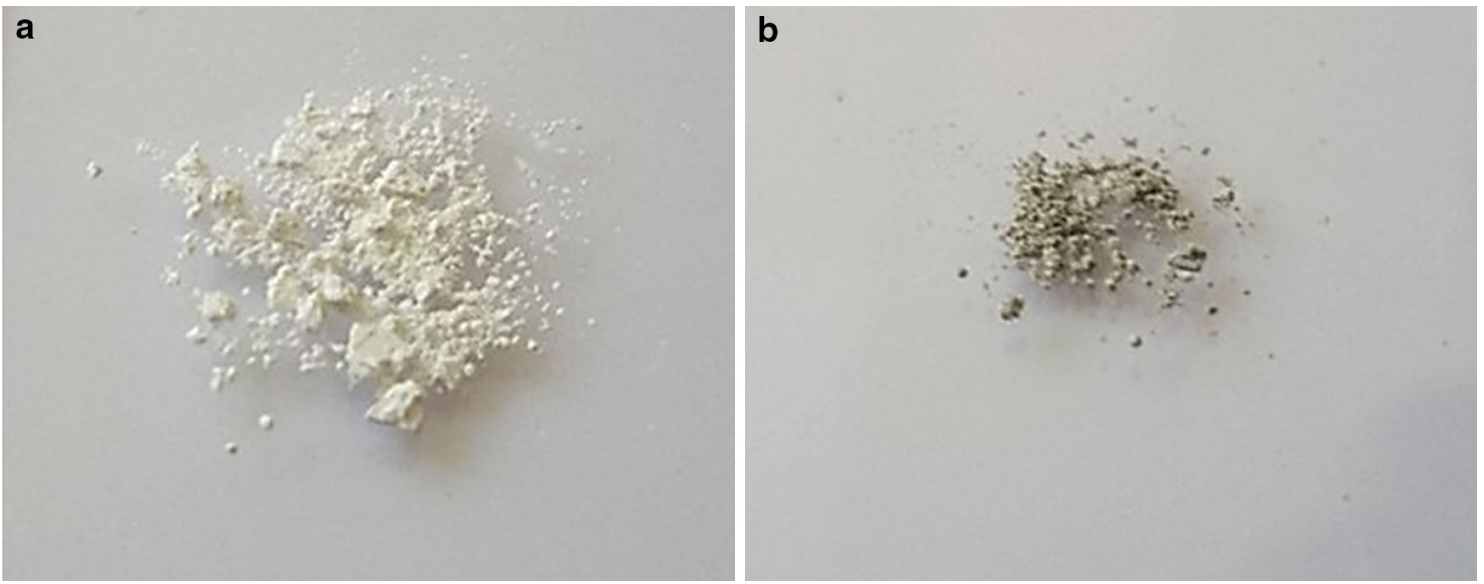

Fig. 3 Color of the ZnO NPs powders obtained following thermal treatments; a ZnO NP 0.15/400 and b ZnO NP 0.1/600
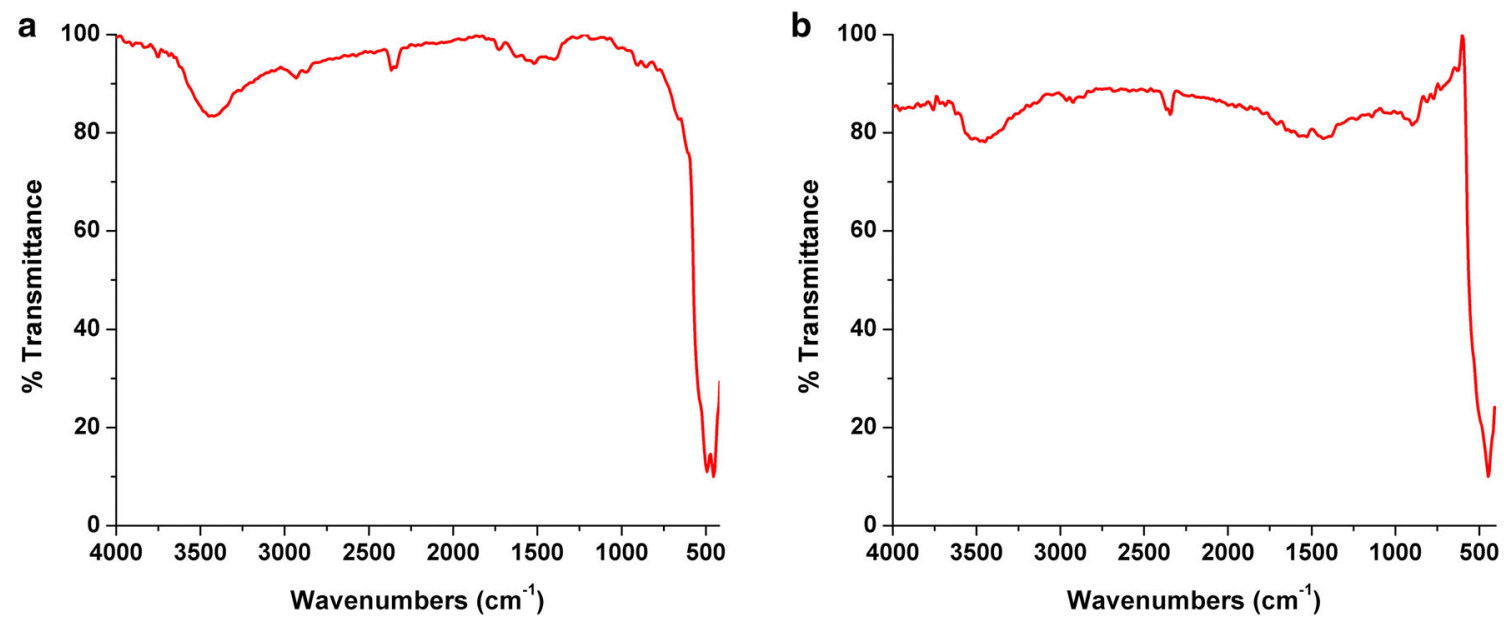

Fig. 4 IR spectra for a ZnO NP 0.15/400 and b ZnO NP 0.1/600 samples
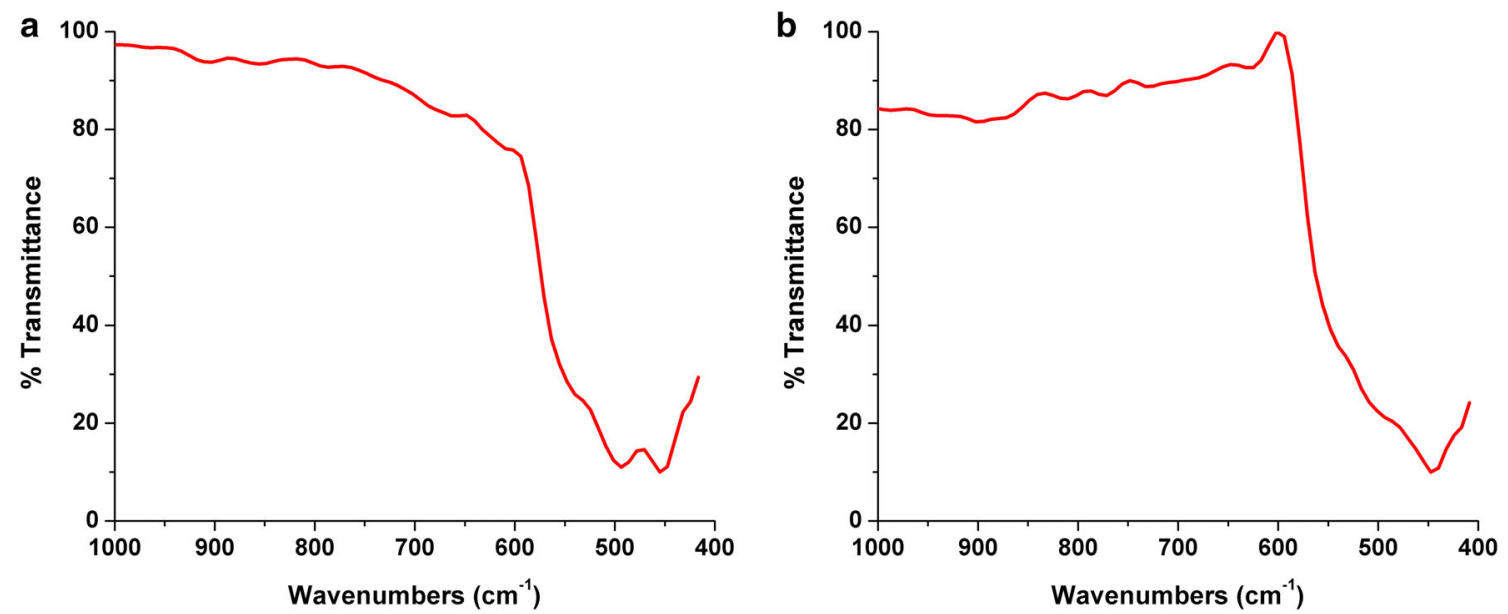

Fig. 5 IR spectra between 1200 and $400 \mathrm{~cm}^{-1}$ for a ZnO NP 0.15/400 and b ZnO NP 0.1/600 samples

between the spectra, indicating that there are no longrange changes in the structure of the samples. This leads to the conclusion that the changes observed in the samples, brought about by the variation in the synthesis parameters, are of a more local type, as indicated by the IR spectroscopy (Figs. 4, 5). 


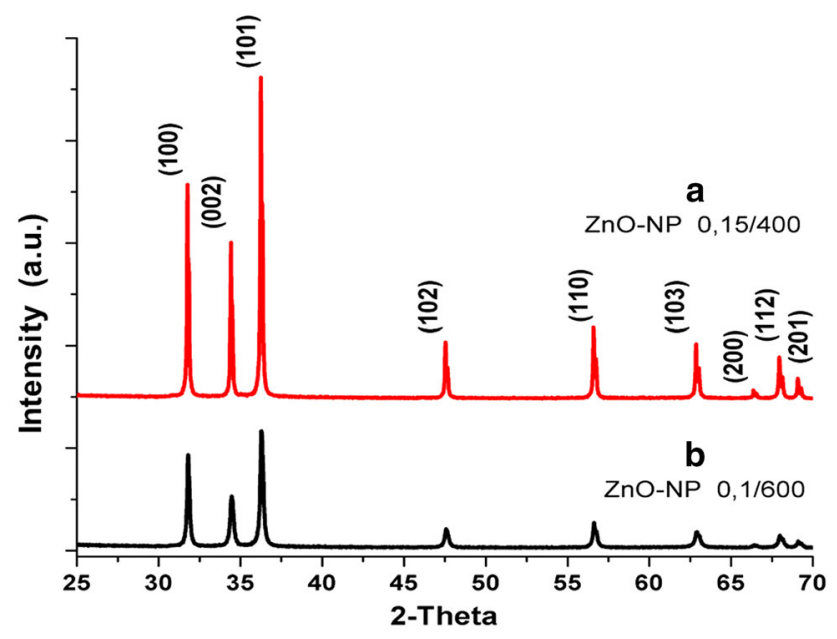

Fig. 6 Diffractograms of X ray corresponding to $a \mathrm{ZnO}$ NP $0.15 / 400$ and $b \mathrm{ZnO}$ NP $0.1 / 600$ samples

\section{Replication of the phytopathogenic fungus $E$. salmonicolor in the laboratory}

When the phytopathogenic fungus was inoculated and allowed to grow in its respective culture medium, it was found that at 16 days its growth was optimal. This result demonstrates that the culture medium, indicated previously, was the most suitable for its growth (Lane et al. 2012). Moreover, it should be noted that for E. salmonicolor, application of the antibiotic oxytetracycline, used in a quantity of $0.03 \mathrm{~g} / \mathrm{L}$, reduced the risk of contamination and allowed culture purity (Kuang-Ren and Tzeng 2009).

The method of maintaining the fungi used in this study was periodic replanting, a technique that ensures good survival of the cultures over short periods of time. However, for greater reliability in the results, other methods for maintaining microbial strains should be sought, such as that recommended by Aleman et al. (2005) and Huertas et al. (2006), where the viability, purity and genetic stability of the cultures is guaranteed.

\section{Evaluation of antifungal effect of ZnO NPs on in vitro cultivation of $E$. salmonicolor}

\section{Growth of E. salmonicolor in ZnO NP 0.15/400 system}

Figure 7 compares the control, the treatment with the fungicide, and the $9 \mathrm{mmol} \mathrm{L}^{-1}$ concentration treatment with $\mathrm{ZnO}$ NP $0.15 / 400$. The images show the characteristics of macroscopic growth of E. salmonicolor at 16 days of age on potato dextrose agar-based culture medium with oxytetracycline. Looking at the photographs, the efficiency of this concentration of $\mathrm{ZnO}$ NPs treatment on the inhibition of fungal growth is clear. According to these results, at 16 days, the treatment with the fungicide did not inhibit or retard the growth of the fungus, while the ZnO NPs treatment did. As a result of this initial observation, morphological changes were evident in form, margin, texture, and area of fungal growth.

In order to determine the percent growth inhibition of $E$. salmonicolor caused by the treatment with $\mathrm{ZnO} \mathrm{NP} 0.15 /$ 400 , taking the control and the fungicide as references, use was made of the methodology and the equation indicated in "Percent (\%) inhibition"; the results obtained are shown in Table 1. Measurements of the area of the fungus were
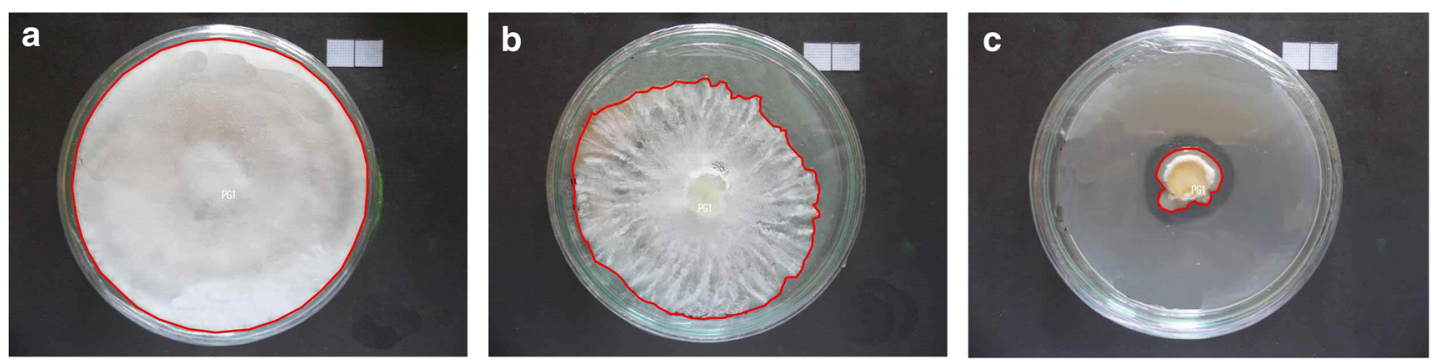

FORM (b). Filamentous

MARGIN

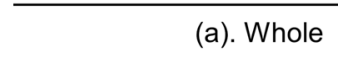

(a). Cottony

(a). $84.62 \mathrm{~cm}^{2}$ (b). Filamentous TEXTURE

(b). Plush

GROWTH AREA

(b). $54.54 \mathrm{~cm}^{2}$

(a). $84.62 \mathrm{~cm}^{2}$

(c). Irregular

(c). Lobular

(c). Glabrous

(c). $4.05 \mathrm{~cm}^{2}$

Fig. 7 Macroscopic mycelial growth of the fungus E. salmonicolor at 16 days of age: a control, $\mathbf{b}$ treatment with fungicide, and $\mathbf{c}$ treatment with a $9 \mathrm{mmol} \mathrm{L}^{-1}$ concentration of nanoparticles of the $\mathrm{ZnO} \mathrm{NP} 0.15 / 400$ system 


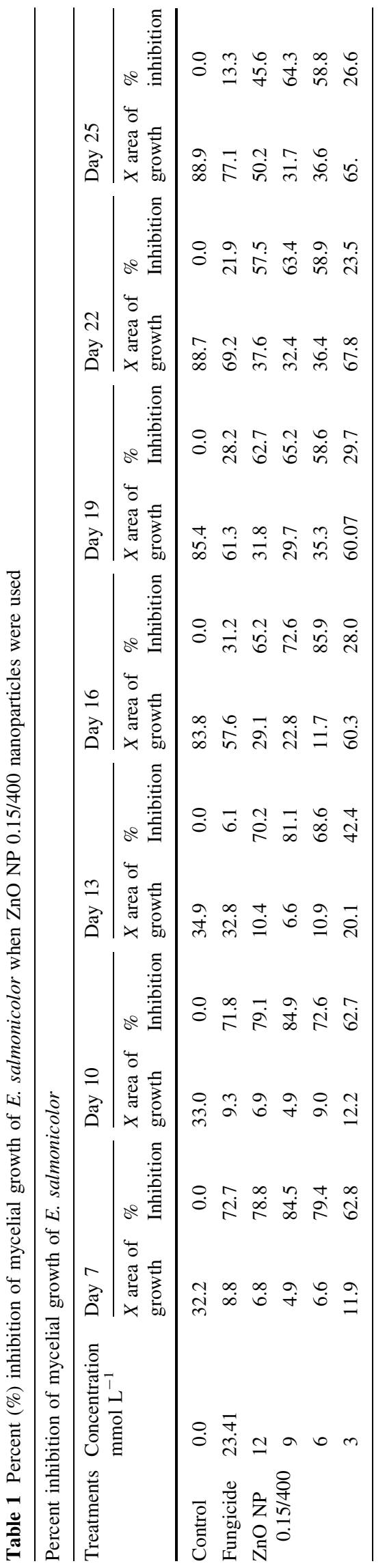

performed on assigned follow-up days, and these were used to calculate percent inhibition, revealing that $\mathrm{ZnO} \mathrm{NP}$ $0.15 / 400$ caused significant inhibitory effects on the growth of the fungi, when compared to the control (Table 1).

Observing the results in Table 1, it became clear that the highest percent inhibition was found on day 10, with an $84.9 \%$ inhibition, which decreased over time to the end of the experiment. On day 25 , a $64.3 \%$ inhibition was obtained. This indicates that the NPs initially showed high antifungal capacity, which decreased over time without ever completely losing their inhibitory action: the lowest percentage was $23.5 \%$ for the $3 \mathrm{mmol} \mathrm{L}^{-1}$ concentration on day 22, against $21.9 \%$ obtained with the fungicide treatment on the same day. Considering the values of percent inhibition recorded in Table 1, it can be concluded that the presence of $\mathrm{ZnO} \mathrm{NP} 0.15 / 400$ in the cultures significantly affected the growth of E. salmonicolor.

Based on the above and according to the ANOVA two-way analysis used in this study for E. salmonicolor, when it was subjected to the treatments, significant differences in the growth of the fungus were found: an ANOVA of $F=25.6447$ and a value of $p<0.0001$. The biggest differences in the growth of the fungus were found in the treatments with $\mathrm{NP}$ at concentrations of 12,9 and $6 \mathrm{mmol} \mathrm{L}^{-1}$, with the $9 \mathrm{mmol} \mathrm{L}{ }^{-1}$ treatment standing out as it exerted a greater control on the mycelial growth of the fungus, whereas at a concentration of $3 \mathrm{mmol} \mathrm{L}^{-1}$ there was no significant difference between the effect of the $\mathrm{ZnO}$ NPs and the fungicide.

Significant differences were also observed between blocks (days), encountering an ANOVA of $F=30.7202$ and a value of $p<0.0001$. In Fig. 8, all the results of the tests conducted can be seen, showing that on days 10, 19 and 25 the $9 \mathrm{mmol} \mathrm{L}^{-1}$ concentration of the $\mathrm{ZnO} \mathrm{NP} \mathrm{0.15/}$ 400 system continued to show a significant inhibition of fungal mycelial growth.

Growth of E. salmonicolor on the system with ZnO NP 0.1/ 600

To determine the effect of the parameters of synthesis on the antifungal capacity of the $\mathrm{ZnO} \mathrm{NPs}$, a similar test was carried out to that carried out with ZnO NP 0.15/400 samples described above, but using nanoparticles from the $\mathrm{ZnO}$ NP $0.1 / 600$ system. To do this, growth of $E$. salmonicolor was recorded and the percent inhibition calculated using these data. Figure 9 shows the results obtained for the treatment with a concentration of $12 \mathrm{mmol} \mathrm{L}^{-1}$ of $\mathrm{ZnO} \mathrm{NP} 0.1 / 600$, for which the inhibitory effect using these new nanoparticles was most evident. The results in Fig. 9 showed growth inhibition of E. salmonicolor until day 10 , at which point it is clear that the NP used here were less efficient in the control of mycelial 
Fig. 8 Antifungal activity of different concentrations of $\mathrm{ZnO}$ NP $0.15 / 400$ on E. salmonicolor
Inhibition of mycelial growth of E. salmonicolor

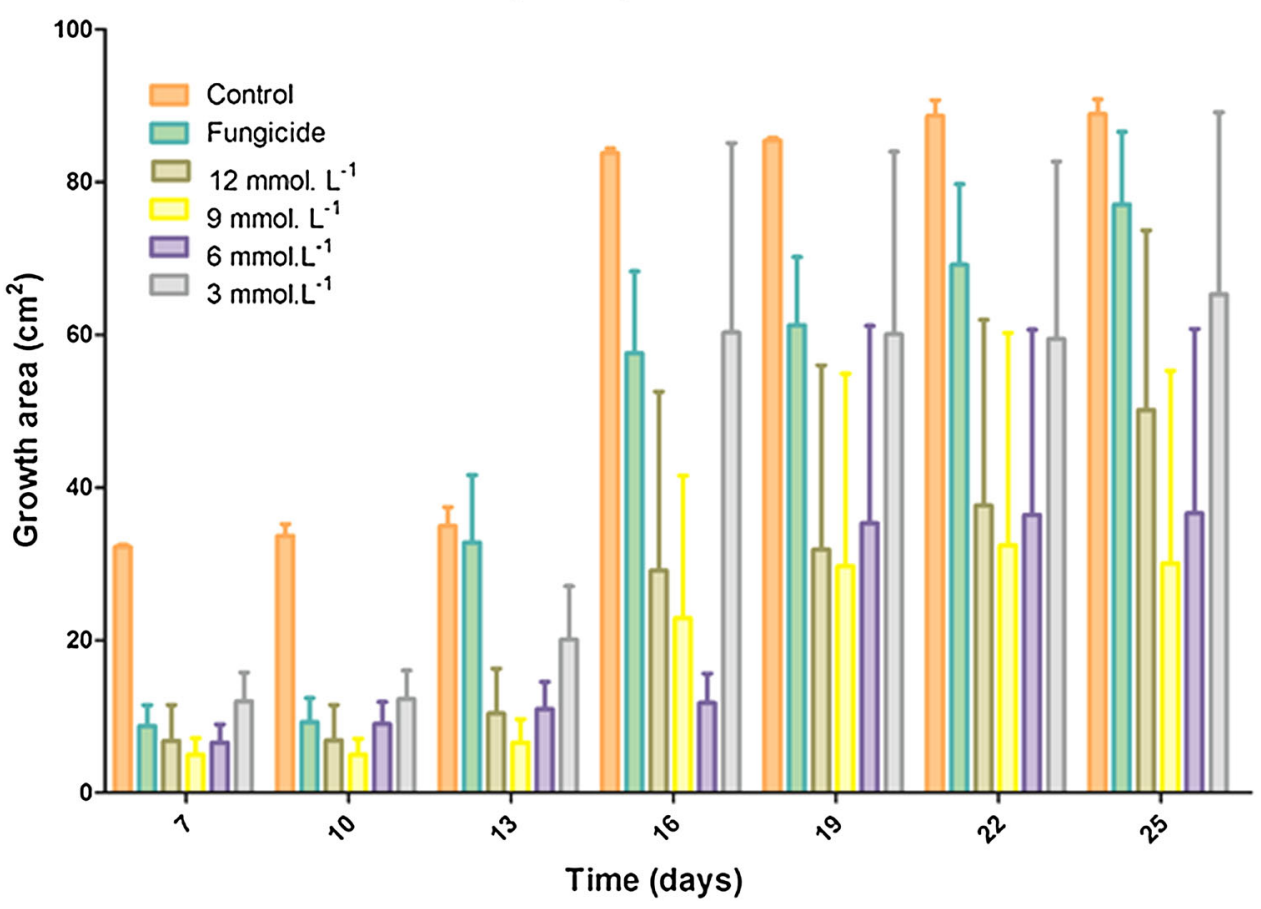

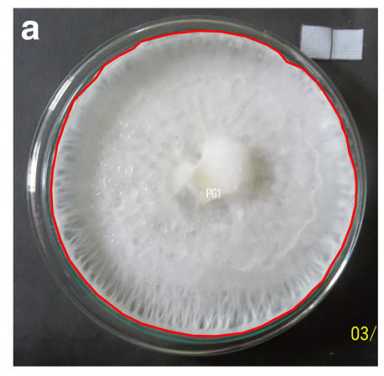

(a). Circular

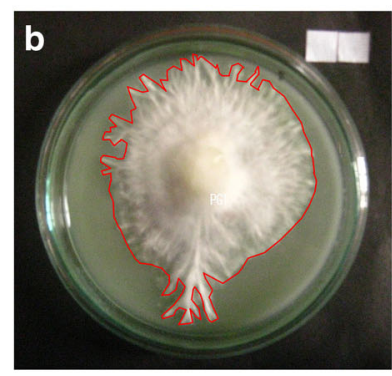

FORM

\begin{tabular}{ccc}
\hline (a). Circular & (b). Filamentous & (c). Irregular \\
& MARGEN & \\
\hline (a). Smooth & (b). Filamentous & (c). Wavy \\
& TEXTURE & \\
\hline (a). Cottony & (b). Plush & (c). Plush \\
& AREA OF GROWTH & \\
\hline
\end{tabular}

(a). $60.3 \mathrm{~cm}^{2}$

(b). $35.0 \mathrm{~cm}^{2}$

(c). $27.9 \mathrm{~cm}^{2}$

Fig. 9 Macroscopic mycelial growth of E. salmonicolor at 10 days of age: a control, b treatment with fungicide, and c treatment with $12 \mathrm{mmol} \mathrm{L}^{-1}$ of $\mathrm{ZnO} \mathrm{NP} 0.1 / 600$

growth compared to the nanoparticles for the $\mathrm{ZnO} \mathrm{NP} 0.15 /$ 400 system (Fig. 7). It is important to note that in this trial it was not possible to record data for all of the proposed days, since by day 16 , the fungus covered the entire petri dish. Therefore, a statistical study was not performed because there were insufficient data to obtain a reliable result.
Table 2 shows the values obtained for percent inhibition of fungal growth in E. salmonicolor in the cultures treated with nanoparticles from the $\mathrm{ZnO}$ NP $0.1 / 600$ system, taking as references the control and the treatment with the fungicide. The results indicate that the highest percent inhibition was $71.3 \%$ on day 7 , against a $51.1 \%$ on day 10 , compared to the fungicide treatment, which was $66.8 \%$ on 
Table 2 Percent (\%) inhibition of mycelial growth of E. salmonicolor when nanoparticles from the ZnO NP 0.1/600 system are used in the treatment

\begin{tabular}{|c|c|c|c|c|c|}
\hline \multicolumn{6}{|c|}{ Percent inhibition of mycelial growth of E. salmonicolor } \\
\hline \multirow[t]{2}{*}{ Treatment } & \multirow[t]{2}{*}{ Concentration $\mathrm{mmol} \mathrm{L}^{-1}$} & \multicolumn{2}{|l|}{ Day 7} & \multicolumn{2}{|l|}{ Day 10} \\
\hline & & $X$ area of growth $\left(\mathrm{cm}^{2}\right)$ & $\%$ Inhibition & $X$ area of growth $\left(\mathrm{cm}^{2}\right)$ & $\%$ Inhibition \\
\hline Control & 0.0 & 52.2 & 0.0 & 65.2 & 0.0 \\
\hline Fungicide & 23.4 & 18.3 & 66.8 & 34.7 & 46.7 \\
\hline \multirow[t]{4}{*}{ ZnO NP 0.1/600 } & 12 & 15.0 & 71.3 & 31.9 & 51.1 \\
\hline & 9 & 20.5 & 58.3 & 36.1 & 44.6 \\
\hline & 6 & 26.7 & 48.9 & 49.8 & 23.6 \\
\hline & 3 & 33.3 & 36.9 & 56.01 & 14.1 \\
\hline
\end{tabular}

day 7 and $46.7 \%$ on day 10 . These data indicate a favorable effect of NP on the control of mycelial growth of $E$ salmonicolor. However, if the data in Table 2 ( $\mathrm{ZnO}$ NP $0.1 / 600$ ) are compared with those in Table 1 ( $\mathrm{ZnO}$ NP $0.15 / 400)$, an appreciable difference is observed, inhibition being more efficient for the second system.

The less favorable results obtained with the $\mathrm{ZnO}$ NP 0.1/ 600 sample (Fig. 9; Table 2), compared to those of $\mathrm{ZnO}$ NP 0.15/400 (Fig. 7; Table 1) can be explained considering the formation of clusters or hard agglomerates, as shown in Fig. 2. These would decrease the surface area of the $\mathrm{ZnO}$, leading to a reduction in its activity against the fungus, as can be seen in Fig. 9, where the fungus almost completely filled the petri dishes at 10 days of age. Moreover, there is evidence that the nature of each of the two systems of synthesized ZnO NPs is different, defined by changes in the conditions of synthesis. First, the samples had different colors (Fig. 3). This could be caused by the variation in the concentration and nature of the defects, a condition that would be expected to affect the functionality of the ceramic powders (Greenwood and Earnshaw 1997). Second, the IR spectra corresponding to these two samples (Figs. 4, 5) showed differences in the location of the bands, which implies changes in the structure of the solids, despite being similar chemically and structurally (Fig. 6).

Treatment with the fungicide, meanwhile, was not significant and did not produce an appreciable inhibition of growth of the fungi studied. This can be explained considering that the conditions used in the laboratory are different from those used in the field, which could result in changes in the mode of inhibitory action on the fungus studied. Based on the results obtained, it can be concluded that under in vitro conditions, in which the test was conducted, the $\mathrm{ZnO}$ NPs have a greater effect of inhibition of mycelial growth of E. salmonicolor compared to the reference fungicide used, copper oxychloride. However, to have more conclusive data on this antifungal effect, further testing with other fungicides used to control pink disease should be carried out.

\section{Identification of morphological and ultrastructural damage to the fungus determined using HROM and TEM}

Given that the ZnO NP 0.15/400 nanoparticles were those that showed the highest antifungal ability with $E$. salmonicolor, morphological and ultrastructural changes in the fungi that interacted with these were analyzed.

\section{Morphological changes of E. salmonicolor observed with HROM}

Figure 10 shows images of the mycelia obtained through imprinting, the procedure described in "High-resolution optical microscopy". The hyphae were seen to have smooth walls, a "network" structure and well-defined septa (Fig. 10a) that stained better than the interior of the hypha.

In Fig. 10b, it can be seen that the fibers of the hyphae tend to clump and that the staining used had a stronger affinity towards the interior, meaning that the septa were not visible. In the 12,9 , and $6 \mathrm{mmol} \mathrm{L}^{-1}$ treatments with the $\mathrm{ZnO} \mathrm{NP} 0.15 / 400$, there was a deformation in the growth patterns as a result, since the fibers of the hyphae were noticeably thinner and tended to clump (Fig. 10c-e). From the observations, it is clear that ZnO NP 0.15/400 inhibited the growth of E. salmonicolor.

\section{Ultrastructural changes of E. salmonicolor observed} with TEM

In E. salmonicolor sections at 16 days of growth, the presence was observed, in the control, of organelles such as vacuoles (V) and mitochondria (Mit) in a conserved cytoplasm (Cyt), with a defined cell wall $(\mathrm{Cw})$, which caused it 

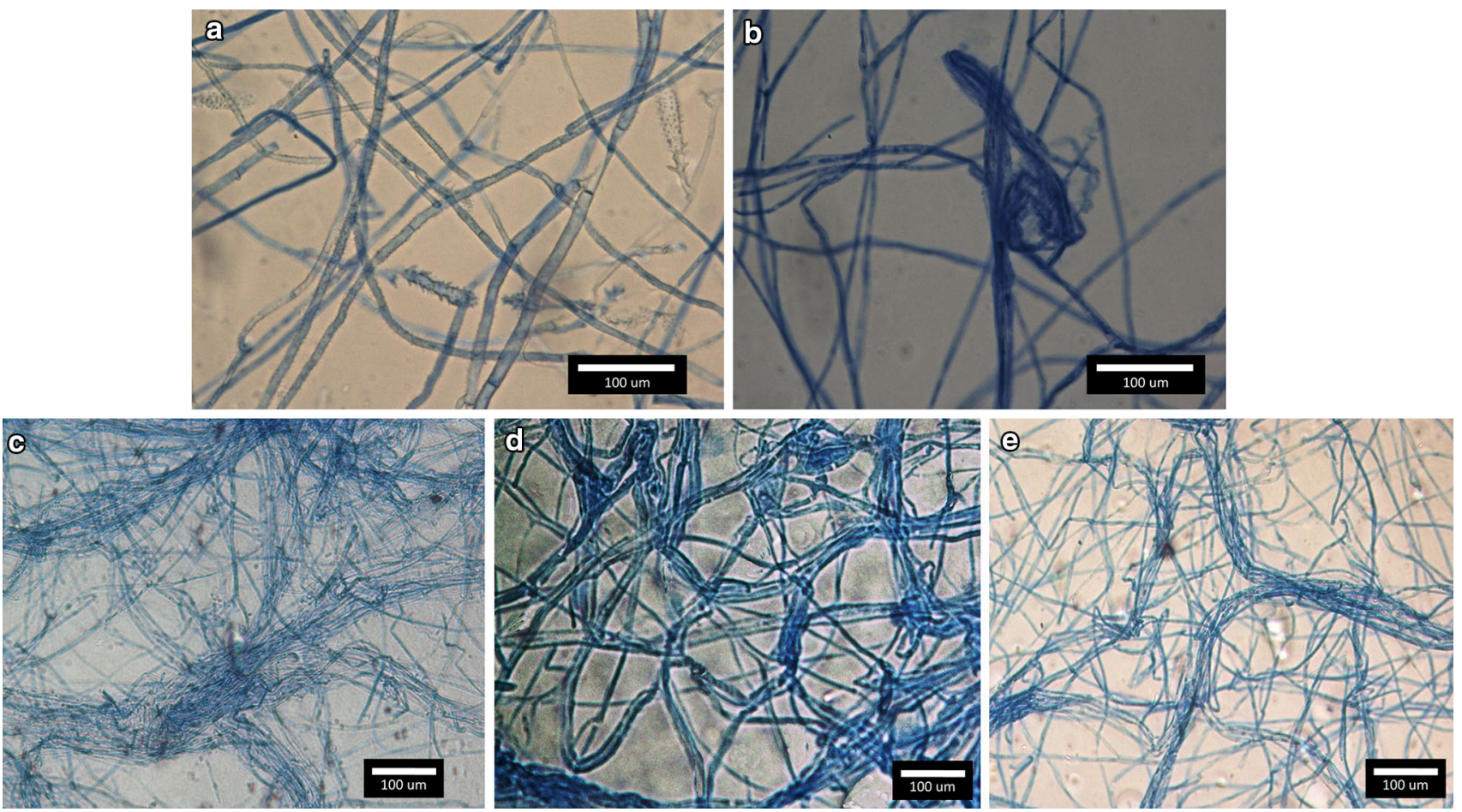

Fig. 10 Image of hyphal structures of E. salmonicolor. a Control, b treatment with fungicide, $\mathbf{c}$ treatment with $12 \mathrm{mmol} \mathrm{L}^{-1}, \mathbf{d} 9 \mathrm{mmol} \mathrm{L}-1$, and e $6 \mathrm{mmol} \mathrm{L}^{-1} \mathrm{ZnO} \mathrm{NP} \mathrm{0.15/400}$

to be more electron-dense (Romero de Pérez 2003) on observing it in TEM, Fig. 11a, while in the treatment with the fungicide, a fractionation of the cell wall was observed, a change that cannot be considered to be relevant as its structure was similar to that of the control, Fig. $11 \mathrm{~b}$. Finally, in the fungal sections treated with $\mathrm{ZnO}$ NP 0.15/ $400\left(9 \mathrm{mmol} \mathrm{L}^{-1}\right)$, a uniform thickening of the cell wall was seen, with a noticeable liquefaction of the cytoplasmic contents, making it less electron-dense, Fig. 11c. A similar effect was produced with the $12 \mathrm{mmol} \mathrm{L}^{-1} \mathrm{ZnO} \mathrm{NP} 0.15$ / 400 , where a number of vacuoles (V) and detachment of the cell wall $(\mathrm{Cw})$ were also seen, Fig. $11 \mathrm{~d}$.

In summary, the effects observed for the interaction of nanoparticles of the $\mathrm{ZnO} \mathrm{NP} 0.15 / 400$ system on $E$. salmonicolor correspond in the main to significant morphological changes in the mycelium (Figs. 10, 11). In general, the results obtained in this study provide interesting elements for putting together a mechanism that explains and accounts for the toxicity of the ZnO NPs (Buerki-Thurnherr et al. 2012; Sharma 2011), specifically their antifungal activity. Taking account of conventional criteria used to classify antifungal compounds, an important aspect to consider is the "action site" of the nanoparticles (on the cell membrane, cell wall, DNA or RNA), as well as its surface characteristics. Therefore, in putting together a possible mechanism to account for the antifungal capacity of $\mathrm{ZnO} \mathrm{NPs}$, the wall of the fungus might be viewed as a target, also taking into account the surface physicochemical characteristics of $\mathrm{ZnO}$ (Altunbek et al. 2014; Wöll 2007), as well as its other physicochemical characteristics-size and shape, for examplethat can also affect the toxicity of this oxide (Mu et al. 2014). The fungal wall, in controlling cell permeability, is the part of the cell that interacts with the external environment, and thus with the $\mathrm{ZnO}$ NPs present in the fungal culture of interest in this work. This part of the fungal cell is composed mainly of polysaccharides and proteins. Specifically, there are $\beta$-1,3-D-glucan and $\beta-1,6$-D-glucan macroproteins, chitin, proteins, and lipids, and among the polysaccharides, chitin, glucan, and mannan or galactomannan (Pontón 2008) predominate.

One possible mechanism of the antifungal action by the ZnO-NPs may take account of the action of ROS and/or $\mathrm{Zn}^{2+}$ on $N$-acetylglucosamine ( $N$-acetyl-D-glucose-2amine) or on $\beta$-1 3-D-glucan synthase (FKs1p). The ROS are generated by the nanoparticles (Lipovsky et al. 2009, 2011), while $\mathrm{Zn}^{2+}$ is a product of the dissolution of the nanoparticles in the culture medium ( $\mathrm{Lv}$ et al. 2012; Mudunkotuwa et al. 2012; Reed et al. 2012; Xia et al. 2008). $\mathrm{N}$-acetylglucosamine is involved in the synthesis of the chitin (a polysaccharide of great importance in the structure of the cell wall), while the $\beta-13$-D-glucan synthase participates in the synthesis of $\beta-1,3$-D-glucan (another important component of the cell wall in fungi). This 

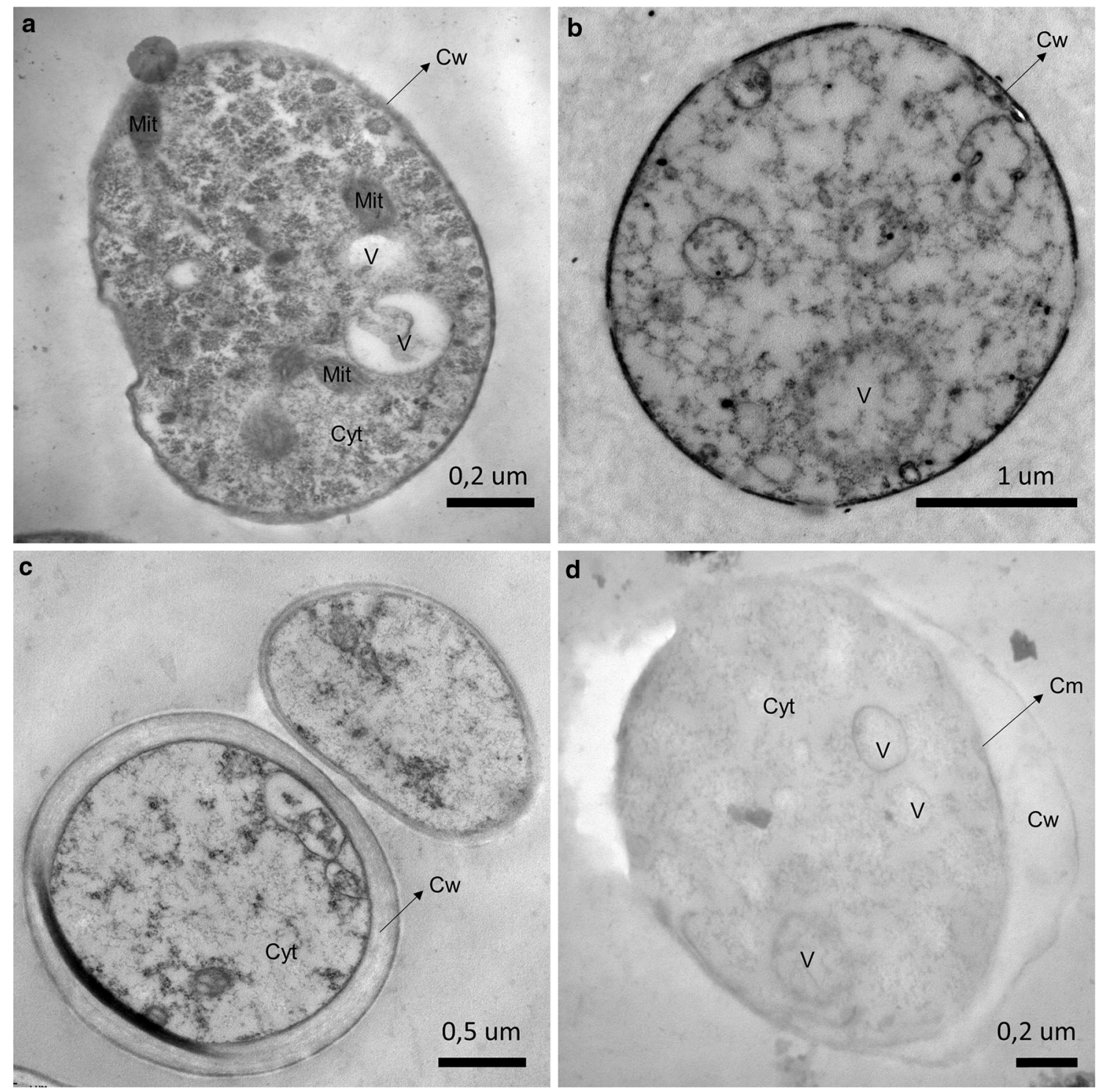

Fig. 11 TEM of sections of E. salmonicolor: a Control, and subjected to treatment with $\mathbf{b}$ the fungicide copper oxychloride, $\mathbf{c} \mathrm{ZnO} \mathrm{NP} 0.15 / 400$ at $9 \mathrm{mmol} \mathrm{L}^{-1}$, and $\mathbf{d ~} \mathrm{ZnO} \mathrm{NP} 0.15 / 400$ at $12 \mathrm{mmol} \mathrm{L}^{-1}$ [vacuoles (V), mitochondria (Mit), cell wall (Cw), and cytoplasm (Cyt)]

would echo the effect of penicillin on the bacterial cell wall (Park and Stromistger 1957).

Although the action of nanoparticles on biological systems has already been the subject of research (Colvin and Kulinowski 2007; Klein 2007; Rahman et al. 2013), more studies are required to look at the action of nanoparticulate zinc oxide on chitin and glucan, due to the effects observed in this work of ZnO-NPs on E. salmonicolor a noticeable thickening of the cell wall and liquefaction of the cytoplasmic contents (Figs. 10, 11). Such studies ought to consider the chemical composition of the wall, and determine how the ZnO NPs might control or inhibit synthesis of the enzymes of chitin and glucan, taking as reference the knowledge of classic antifungal inhibitors of glucan (Douglas 2001; Romero et al. 2005) and chitin (Gongora
2002; Merzendorfer 2006) synthesis, paying special attention to the peculiarities of the toxicity of the nanoparticles (Zucolotto et al. 2013).

Recent work indicates that the nanoparticles induce oxidative stress (Xia et al. 2008). The harmful effects appear to be exerted either directly on the target tissue, due to the toxicity of ROS derivatives, or indirectly as the result of the effect of these derivatives on the production of mediators of the inflammatory and immunization systems, primarily proinflammatory co-toxins. This oxidative stress may disable antiproteases while at the same time activating metalloproteases, thereby encouraging proteolysis and uncontrolled cell destruction. Some authors (L'Azou and Marano 2011) suggest that inflammation is a primary response and oxidative stress a consequence of this. As such, nanoparticles 
would be recognized by the body as foreign matter that must be removed by means of the inflammatory reaction, for example an increase in the size of the vacuoles and/or of the cell wall, as shown in Fig. 11. The interaction between the nanoparticles and the proteins of the biological system plays a definitive role in their ability to be recognized by the cells of the immune system responsible for their elimination, as well as by the tissue of the cell wall, the target of the nanoparticles, that could emit pro-inflammatory signals. Inflammation may accelerate the production of ROS and reduce the antioxidant defensive capacity, promoting oxidative stress and the associated tissue damage.

\section{Conclusions}

A methodology was constructed that enabled the synthesis of $\mathrm{ZnO}$ nanoparticles in a controlled and reproducible manner. These nanoparticles demonstrated an antifungal effect on Erythricium salmonicolor, a pathogen that causes the coffee crop disease known as pink disease. Based on the results, in order to ensure adequate antifungal functionality of the $\mathrm{ZnO}$ NPs, synthesis parameters require to be rigorously controlled: any change in these could affect nanoparticle behavior. The $\mathrm{ZnO}$ NPs with sizes in the range between 20 and $45 \mathrm{~nm}$ showed a significant antifungal capacity on mycelial growth of E. salmonicolor in vitro and using these sizes at a concentration of $6 \mathrm{mmol} \mathrm{L}^{-1}$ gave a substantial inhibition. The $0.15 / 400$ system $\mathrm{ZnO}$ NP nanoparticles caused liquefaction of cytoplasmic contents, making the cytoplasm less electron-dense and producing a notable detachment of the fungal cell wall. These effects ought to be studied more closely as they may prove to be representative when considering the mechanism of action of $\mathrm{ZnO}$ NPs on destructive, disease-causing fungi.

Acknowledgements We are grateful to COLCIENCIAS for funding relating to project code Number 110365842673 COLCIENCIAS ID 4241 and to the VRI for providing logistical support. We are especially grateful to Colin McLachlan for suggestions relating to the English text.

Open Access This article is distributed under the terms of the Creative Commons Attribution 4.0 International License (http:// creativecommons.org/licenses/by/4.0/), which permits unrestricted use, distribution, and reproduction in any medium, provided you give appropriate credit to the original author(s) and the source, provide a link to the Creative Commons license, and indicate if changes were made.

\section{References}

Aleman ZW, Díaz ER, Molina I (2005) Comunicación breve: Conservación de Microorganismos: ¿Que debemos conocer? Rev Cuba Hig Epidemiol 43(3):1-4
Altunbek M, Baysal A, Çulha M (2014) Influence of surface properties of zinc oxide nanoparticles on their cytotoxicity. Colloids Surf B Biointerfaces 121:106-113. doi:10.1016/j. colsurfb.2014.05.034

Alwan RM, Kadhim QA, Sahan KM, Ali RA, Mahdi RJ, Kassim NA, Jassim AN (2015) Synthesis of zinc oxide nanoparticles via solgel route and their characterization. Nanosci Nanotechnol 5:1-6. doi:10.5923/j.nn.20150501.01

Anand K, Varghese S, Kurian T (2014) Synthesis of ZnO nano rods through mechano-chemical route: a solvent free approach. Int J Theor Appl Sci 6(1):87-93

Auer G, Griebler WD, Jahn B (1998) Industrial inorganic pigments, 2nd edn. Wiley $\mathrm{VCH}$, Toronto

Avila H, Cruz AM, Villegas M, Caballero AC, Rodríguez-Páez JE (2004) Estudio comparativo de dos metodos de sintesis para la obtención de polvos cerámicos de ZnO-Pr. Bol Soc Esp Ceram 43(4):740-744

Blakeslee E, Carl RB, James TE (1962) Photoconductive zinc oxide pigment. US3060134 A

Bogush GH, Zukoski CF IV (1991) Uniform silica particle precipitation: an aggregative growth model. J Colloid Interface Sci 142:19-34. doi:10.1016/0021-9797(91)90030-C

Bozzola JJ, Russell LD (1999) Electron microscopy: principles and techniques for biologists. Jones \& Bartlett Learning, Toronto

Bréchignac C, Houdy P, Lahmani M (2007) Nanomaterials and nanochemistry. Springer Science \& Business Media, Berlin Heilderberg

Buerki-Thurnherr T, Xiao L, Diener L, Arslan O, Hirsch C, MaederAlthaus X, Grieder K, Wampfler B, Mathur S, Wick P, Krug HF (2012) Mechanistic study towards a better understanding of $\mathrm{ZnO}$ nanoparticle toxicity. Nanotoxicology 7:1-15. doi:10.3109/ 17435390.2012 .666575

Cassaignon S, Colbeau CD (2013) Nanomaterials: a danger or a promise?: A chemical and biological perspective. Springer Verlag, London

Cioffi N, Torsi L, Ditaranto N, Tantillo G, Ghibelli L, Sabbatini L, Bleve-Zacheo T, D’Alessio M, Zambonin PG, Traversa E (2005) Copper nanoparticle/polymer composites with antifungal and bacteriostatic properties. Chem Mater 17:5255-5262. doi:10. 1021/cm0505244

Colvin VL, Kulinowski KM (2007) Nanoparticles as catalysts for protein fibrillation. PNAS 104:8679-8680. doi:10.1073/pnas. 0703194104

Dakhlaoui A, Jendoubi M, Samia L, Kanaev A, Jouini N (2009) Synthesis, characterization and optical properties of $\mathrm{ZnO}$ nanoparticles with controlled size and morphology. J Cryst Growth 311:3989-3996. doi:10.1016/j.jcrysgro.2009.06.028

Djurišić AB, Leung YH (2006) Optical properties of $\mathrm{ZnO}$ nanostructures. Small 2:944-961. doi:10.1002/smll.200600134

Douglas CM (2001) Fungal $\beta(1,3)$-D-glucan synthesis. Med Mycol 39(1):55-66. doi:10.1080/mmy.39.1.55.66

FNC, Federacion Nacional de Cafeteros de Colombia (2014) Comportamiento de la Industria Cafetera Colombiana 2014. https:// www.federaciondecafeteros.org/static/files/Informe_Industrial_ 2014_Web.pdf

Galvis-García CA (2002) El Mal Rosado del Cafeto. Avances Técnicos Cenicafé 299:1-8

Gongora E (2002) Quitina Sintasas de Entamoeba histolytica: Clonacion y Analisis de la Estructura Primaria. Universidad Autonoma de Nuevo León, San Nicolás de los Garza

Greenwood NN, Earnshaw A (1997) Chemistry of the elements, 2nd edn. Butterworth-Heinemann, Burlington

Guo J, Peng C (2015) Synthesis of $\mathrm{ZnO}$ nanoparticles with a novel combustion method and their $\mathrm{C}_{2} \mathrm{H}_{5} \mathrm{OH}$ gas sensing properties. Ceram Int 41(2-part A):2180-2186. doi:10.1016/j.ceramint. 2014.10.017

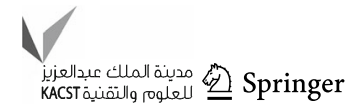


Hardy A, Elen K, Rul H, Den Van, Hardy A (2009) Hydrothermal synthesis of $\mathrm{ZnO}$ nanorods: a statistical determination of the significant parameters in view of reducing the diameter. Nanotechnology 20:055608. doi:10.1088/0957-4484/20/5/ 055608

He L, Liu Y, Mustapha A, Lin M (2011) Antifungal activity of zinc oxide nanoparticles against Botrytis cinerea and Penicillium expansum. Microbiol Res 166(3):207-215. doi:10.1016/j.micres. 2010.03.003

Houdy P, Lahmani M, Marano F (2011) Nanoethics and nanotoxicology. Springer Science \& Business Media, Berlin. doi:10. 1007/978-3-642-20177-6

Huertas SLP, Casas MMP, Morales MB, Moreno ZS, Castaño DM (2006) Implementación y evaluación de dos métodos de conservación y generación de la base de datos del banco de cepas y genes del Instituto de Biotecnología de la Universidad Nacional de Colombia (IBUN). Nova - Publicación Científica 4(5):39-49

Jagadish Ch, Pearton SJ (2011) Zinc oxide bulk, thin films and nanostructures: processing, properties and applications, 1st edn. Elsevier Science, Hong Kong

Janotti A, Van de Walle CG (2009) Fundamentals of zinc oxide as a semiconductor. Rep Prog Phys 72:126-501. doi:10.1088/00344885/72/12/126501

Kahru A, Dubourguier HC (2010) From ecotoxicology to nanoecotoxicology. Toxicology 269(2):105-119. doi:10.1016/j.tox.2009. 08.016

Kisch H (2015) Semiconductor photocatalysis: principles and applications. John Wiley-VCH, Weinheim

Klein J (2007) Probing the interactions of proteins and nanoparticles. Proc Natl Acad Sci 104(7):2029-2030. doi:10.1073/pnas. 0611610104

Klingshirn C (2007a) ZnO: from basics towards applications. Phys Status Solid 244(9):3027-3073. doi:10.1002/pssb.200743072

Klingshirn C (2007b) ZnO: material, physics and applications. ChemPhysChem 8:782-803. doi:10.1002/cphc.200700002

Klingshirn CF, Waag A, Hoffmann A, Geurts J (2010) Zinc oxide: from fundamental properties towards novel applications. Springer Science \& Business Media. doi:10.1007/978-3-642-10577-7

Kołodziejczak-Radzimska A, Jesionowski T (2014) Zinc oxidefrom synthesis to application: a review. Materials 7:2833-2881. doi:10.3390/ma7042833

Kuang-Ren C, Tzeng DD (2009) Thiamine (vitamin B1) plays a critical role on sugar utilization by the phytopathogenic fungus, Ustilago esculenta. Res J Microbiol 4(4):178-185. doi:10.3923/ jm.2009.178.185

Kumar A, Vemula PK, Ajayan PM, John G (2008) Silver-nanoparticle-embedded antimicrobial paints based on vegetable oil. Nat Mater 7(3):236-241. doi:10.1038/nmat2099

L'Azou B, Marano F (2011) Nanoparticle toxicity mechanisms: oxidative stress and inflammation. In: Houdy P, Lahmani M, Marano F (eds) Nanoethics and nanotoxicology. Springer, Berlin, pp 87-109. doi:10.1007/978-3-642-20177-6

Lane CR, Beales BA, Hughes K (2012) Fungal plant pathogens: principles and protocols, 1st edn. CABI, Oxfordshire

Lead JR, Smith EL (2009) Environmental and human health impacts of nanotechnology. Blackwell publishing Ltd., Chippenham

León K, López A, Gago J, Solís J (2011) Síntesis del óxido de cobre nanoestructurado asistida con irradiación gamma o ultrasonido y sus propiedades antimicrobianas, 1st edn. ECIPerú, Lima

Lieber MR, Yu K, Raghavan SC (2006) GraphPad Prism 5: statistics guide. GraphPad Software Inc. Press, San Diego (DNA Repair 5(9):1234-1245)

Lipovsky A, Nitzan Y, Gedanken A (2009) EPR study of visible lightinduced ROS generation by nanoparticles of $\mathrm{ZnO}$. Phys Chem C 113(36):15997-16001. doi:10.1021/jp904864g
Lipovsky A, Nitzan Y, Gedanken A, Lubart R (2011) Antifungal activity of $\mathrm{ZnO}$ nanoparticles - the role of ROS mediated cell injury. Nanotechnology 22(10):105101. doi:10.1088/0957-4484/ 22/10/105101

Lu M, Pichat P (2013) Photocatalysis and water purification: materials for sustainable energy and development. Wiley-VCH Verlag Gmbh \& Co. KGa, Weinheim

Lv J, Zhang S, Luo L, Han W, Zhang H, Yang K, Christie P (2012) Dissolution and microstructural transformation of $\mathrm{ZnO}$ nanoparticles under the influence of phosphate. Environ Sci Technol 46:7215-7221. doi:10.1021/es301027

Ma H, Williams PL, Diamond SA (2013) Ecotoxicity of manufactured $\mathrm{ZnO}$ nanoparticles-a review. Environ Pollut 172:76-85. doi:10.1016/j.envpol.2012.08.011

Maneerat C, Hayata Y (2006) Antifungal activity of $\mathrm{TiO}_{2}$ photocatalysis against Penicillium expansum in vitro and in fruit tests. Int J Food Microbiol 107:99-103. doi:10.1016/j.ijfoodmicro. 2005.08.018

Merzendorfer H (2006) Insect chitin synthases: a review. J Comp Physiol B 176:1-15. doi:10.1007/s00360-005-0005-3

Miao AJ, Zhang X, Luo Z, Chen Ch, Chin WSP (2010) Zinc oxideengineered nanoparticles: dissolution and toxicity to marine phytoplankton. Environ Toxicol Chem 29(12):2814-2822. doi: $10.1002 /$ etc. 340

Mingua L, Suman P, Xue J, Madler L, Damoiseaux RHE (2010) Stability, bioavailability, and bacterial toxicity of $\mathrm{ZnO}$ and irondoped $\mathrm{ZnO}$ nanoparticles in aquatic media. Environ Sci Technol 45(2):755-761. doi:10.1021/es102266g

Moezzi A, McDonagh AM, Cortie MB (2012) Zinc oxide particles: synthesis, properties and applications. Chem Eng J 185:1-22. doi:10.1016/j.cej.2012.01.076

Morkoç H, Özgür Ü (2008) Zinc oxide: fundamentals, materials and device technology. Wiley, Weinheim

Mu Q, David CA, Galceran J, Rey-Castro C, Krzemiński Ł, Wallace R, Bamiduro F, Milne S, Hondow NS, Brydson R, VizcayBarrena G, Routledge M, Jeuken L, Brown S (2014) Systematic investigation of the physicochemical factors that contribute to the toxicity of $\mathrm{ZnO}$ nanoparticles. Chem Res Toxicol 27(4):558-567. doi:10.1021/tx4004243

Mudunkotuwa IA, Rupasinghe T, Chia-Ming Wu, Grassian VH (2012) Dissolution of $\mathrm{ZnO}$ nanoparticles at circumneutral $\mathrm{pH}$ : a study of size effects in the presence and absence of citric acid. Langmuir 28:396-403. doi:10.1021/la203542x

Naranjo M, Vélez LT, Rojano BA (2011) Actividad Antioxidante de Café Colombiano de Diferentes Calidades. Rev Cuba Plantas Med 16(2):164-173

Nieuwenhuizen PJ (2001) Zinc accelerator complexes. Versatile homogeneous catalysts in sulfur vulcanization. Appl Catal A Gen 207(1-2):55-68. doi:10.1016/S0926-860X(00)00613-X

Nohynek GJ, Lademann J, Ribaud C, Roberts MS (2007) Grey goo on the skin? Nanotechnology, cosmetic and sunscreen safety. Crit Rev Toxicol 37(3):251-277. doi:10.1080/10408440601177780

Oberdörster G, Oberdorster E, Oberdorster J (2005) Nanotoxicology: an emerging discipline evolving from studies of ultrafine particles. Environ Health Perspect 113(7):823-839. doi:10. 1289/ehp.7339

Özgür Ü, Alivov YI, Liu C, Teke A, Reshchikov MA, Doğan S, Avrutin V, Cho SJ, Morkoc H (2005) A comprehensive review of $\mathrm{ZnO}$ materials and devices. J Appl Phys 98:1-103. doi:10. $1063 / 1.1992666$

Pandey D, Tripathi N, Tripathi R, Dixit S (1982) Fungitoxic and phytotoxic properties of the essential oil of Hyptis suaveolens/ Fungitoxische und phytotoxische Eigenschaften 28 des ätherischen Öis von Hyptis suaveolens. Zeitschrift Für Pflanzenkrankheiten Und Pflanzenschutz/J Plant Dis Prot 89(6):344-349. Retrieved from http://www.jstor.org/stable/43214961 
Park JT, Stromistger JL (1957) Mode of action of penicillin. Biochemical basis for the mechanism of action of penicillin and for its selective toxicity. Am Assoc Adv Sci 125:99-101. doi:10.1126/science.125.3238.99

Parras P, Martínez-Tomé M, Jiménez AM, Murcia MA (2007) Antioxidant capacity of coffees of several origins brewed following three different procedures. Food Chem 102:582-592. doi:10.1016/j.foodchem.2006.05.037

Patnaik P (2003) Handbook of inorganic chemicals, 1st edn. McGraw-Hill Professional, New York

Pearton SJ, Norton DP, Ip K, Heo YW, Steiner T (2005) Recent progress in processing and properties of $\mathrm{ZnO}$. Prog Mater Sci 50(3):293-340. doi:10.1016/j.pmatsci.2004.04.001

Pontón J (2008) La pared celular de los hongos y el mecanismo de acción de la anidulafungina. Rev Iberoam Micol 25:78-82. doi:10.1016/S1130-1406(08)70024-X

Poynton HC, Lazorchak JM, Impellitteri CA, Smith ME, Rogers K, Patra M, Hammer KA, Allen HJ, Vulpe CD (2011) Differential gene expression in Daphnia magna suggests distinct modes of action and bioavailability for $\mathrm{ZnO}$ nanoparticles and $\mathrm{Zn}$ ions. Environ Sci Technol 45(2):762-768. doi:10.1021/es102501z

Rahman M, Laurent S, Tawil N, Yahia L, Mahmoudi M (2013) Protein-nanoparticle interactions. Springer, Heidelberg. doi:10. 1007/978-3-642-37555-2

Ram MK, Andreescu S, Ding H (2011) Nanotechnology for environmental decontamination. McGraw-Hill, New York

Ray PC, Yu H, Fu P (2009) Toxicity and environmental risks of nanomaterials: challenges and future needs. J Environ Sci Health C Environ Carcinog Ecotoxicol Rev 27(1):1-35. doi:10.1080/ 10590500802708267

Reed RB, Ladner D, Higgins Ch, Westerhoff P, Ranville J (2012) Solubility of nano-zinc oxide in environmentally and biologically important matrices. Environ Toxicol Chem 31(1):93-99. doi:10.1002/etc.708

Rodríguez P (2001) Biodiversidad de los hongos fitopatógenos del suelo de México. Acta Zoológica Mexicana. $\mathrm{N}^{\circ}$ Special 1: 53-78

Rodríguez-Páez JE, Caballero AC, Villegas M, Moure C, Durán P, Fernández JF (2001) Controlled precipitation methods: formation mechanism of $\mathrm{ZnO}$ nanoparticles. Eur Ceram Soc 21:925-930. doi:10.1016/S0955-2219(00)00283-1

Romero de Pérez G (2003) Microscopía electrónica de transmisión (MET) área biomédica: teoría y práctica. Academia Colombiana de Ciencias Exactas, físicas y Naturales, Bogotá
Romero M, Cantón E, Pemán J, Gobernado M (2005) Antifúngicos inhibidores de la síntesis del glucano. Rev Esp Quimioter 18:281-299

Sapkota A, Anceno AJ, Baruah S, Shipin OV, Dutta J (2011) Zinc oxide nanorod mediated visible light photoinactivation of model microbes in water. Nanotechnology 22(21):215703. doi:10. 10888/0957-4484/22/21/215703

Sawai J, Shoji S, Igarashi H, Hashimoto A, Kokugan T, Shimizu M, Kojima H (1998) Hydrogen peroxide as an antibacterial factor in zinc oxide powder slurry. J Ferment Bioeng 86(5):521-522. doi:10.1016/S0922-338X(98)80165-7

Sharma V (2011) An investigation into the mechanism of toxicity of zinc oxide nanoparticles. Thesis of University of Bradford. http://hdl.handle.net/10454/5421

Sharma D, Rajput J, Kaith B, Kaur M, Sharma S (2010) Synthesis of $\mathrm{ZnO}$ nanoparticles and study of their antibacterial and antifungal properties. Thin Solid Films 519(3):1224-1229. doi:10.1016/j. tsf.2010.08.073

Socrates G (2004) Infrared and Raman characteristic group frequencies: tables and charts. Wiley, Chichester

Vogel D, Krüger P, Pollmann J (1995) Ab initio electronic-structure calculations for II-VI semiconductors using self-interactioncorrected pseudopotentials. Phys Rev B 52:R14316. doi:10. 1103/PhysRevB.52.R14316

Wöll C (2007) The chemistry and physics of zinc oxide surfaces. Prog Surf Sci 82:55-120. doi:10.1016/j.progsurf.2006.12.002

Xia T, Kovochich M, Liong M, Mädler L, Gilbert B, Shi H, Yeh JI, Zink JI, Nel AE, Xia T, Kovochich M, Liong M, Madler L, Gilbert B, Shi H, Yeh J, Zink J, Nel A (2008) Comparison of the mechanism of toxicity of zinc oxide and cerium oxide nanoparticles based on dissolution and oxidative stress properties. ACS Nano 2(10):2121-2134. doi:10.1021/nn800511k

Klabunde KJ, Richards R (2009) Nanoscale materials in chemistry, 2nd edn. John \& Sons Inc., New Jersey. doi:10.1002/ 0471220620.fmatter_indsub

Yan L, Chuan-Shang L (2009) Hydro/solvo-thermal synthesis of ZnO crystallite with particular morphology. Trans Nonferr Met Soc China 19(2):399-403. doi:10.1016/S1003-6326(08)60285-X

Zar JH (2014) Biostatistical analysis, 5th edn. Pearson Education Limited, Edinburgh Gate

Zucolotto V, Durán N, Guterres SS, Alves OL (2013) Nanotoxicology: materials, methodologies, and assessments. Springer Science \& Business Media, New York. doi:10.1007/978-1-4614-8993-1 